Historic, Archive Document

Do not assume content reflects current scientific knowledge, policies, or practices. 

62.57

TIBRAF ace of at 20

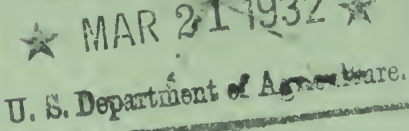

\section{SPRINGTIME}

GARDENS

1931 


\title{
SPRINGTIME GARDENS
}

\section{INCORPORATED}

\author{
Bound Brook, N. J. R. F. D. No. 1.
}

OFFICERS

LOUISE ENGLISH, President

ADDIE W. TILNEY, Vice-President

HARRY C. ENGLISH, Sec'y-Treas.

neo.

\section{Location}

Springtime Gardens are located on the second mountain of the Watchung Range, in what is known as the Washington Valley. They lie north of Bound Brook about four miles, two miles west of Warrenville and about the same distance east of Martinsville. To reach our place from Plainfield follow Somerset Street to Watchung, turn to the left and continue past Pedeflous' Hotel to the end of the macadam road at Warrenville. Here turn to the left, then to the right at next turn and continue straight ahead about two miles. The new State Highway No. 29 runs along the south side of the first mountain of the Watchung Range. To reach Springtime Gardens from this road or from Bound Brook turn off the Highway at Mountain Avenue in Bound Brook and follow the road to crest of first mountain, take left fork and keep on until road forks again. One more turn to the left and about one mile straight road brings you to Springtime Gardens.

To reach us from Highway No. 29 while traveling west to east turn left at the road to Martinsville. Follow this road to where it forks in the village then turn right and continue for about one and three quarter miles.

Phone: Martinsville 204-F-5.

\section{Prices and Shipments}

Prices except where especially noted are $25 \mathrm{c}$ each; $\$ 1.25$ per 6 of one variety; $\$ 2.50$ per dozen of one variety for young plants. Two year plants and field clumps are 50c. each; $\$ 6.00$ per dozen.

Deliveries will be made locally free of charge. Customers residing elsewhere will kindly state their desires concerning shipments. We recommend express, but will ship by parcel post if necessary, parcel post or express charges to be paid by purchaser. Remittance may be made by check or money order.

Greatest care will be taken in the selection and packing of stock. We ship only well developed, sturdy plants, in good condition, carefully counted and checked. Any complaint as to the quality of the stock and the count of same must be made WITHIN 24 HOURS after arrival. No adjustment will be made on claims reported after the expiration of this time. We do not guarantee our stock to thrive under all the various conditions of soil, treatment and location, to which they may be subjected. We guarantee to furnish only high grade stock in first class condition and there our responsibility ends. From that point on, success or failure depends upon $Y O U$. If the stock is not satisfactory upon arrival please notify us at once. 


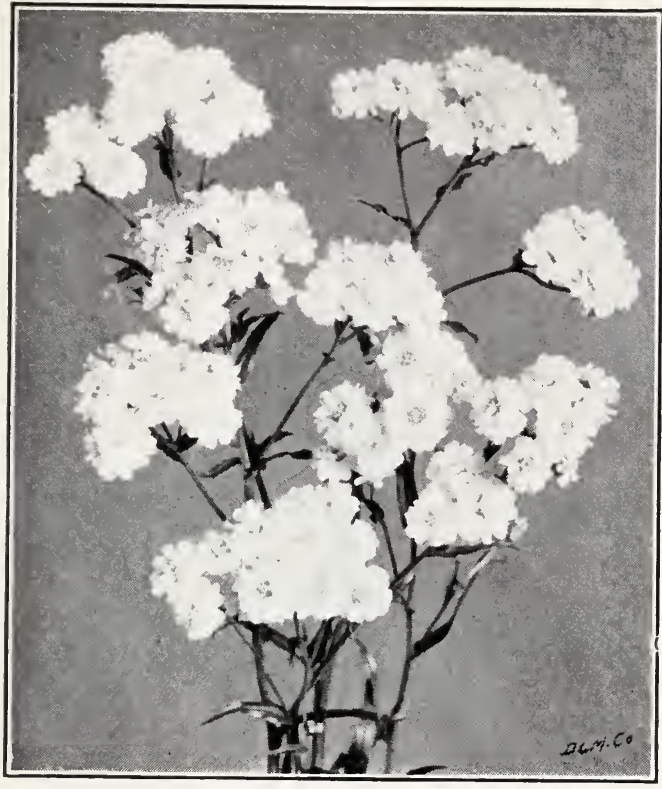

ACHILLEA

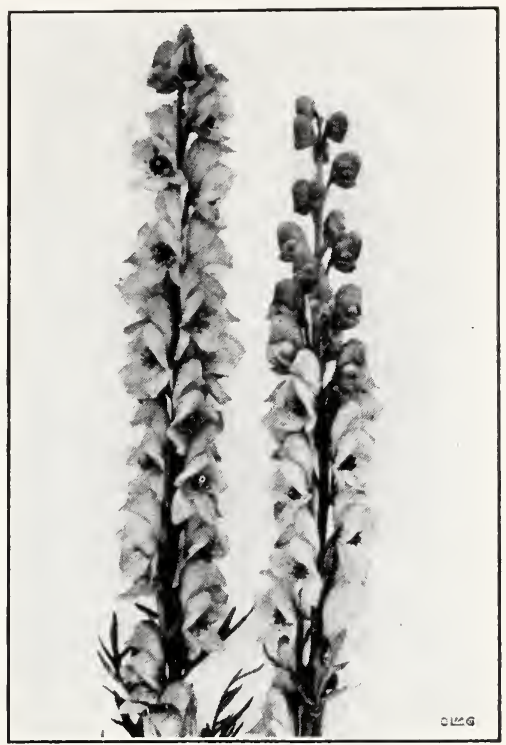

ACONITUM

\section{Hardy Herbaceous Perennials}

Note-Varieties especially suitable for the rock garden are designated with an asterisk $(*)$.

In the back part of the catalog will be found tables giving the common names of plants, listed alphabetically with the botanical name; also, lists of plants suitable for the rock garden and the wild garden, and plants which will grow in partial or full shade. WVe trust our friends will find these tables of value.

ACHILLEA (Milfoil or Yarrow). Sunny, dry locations are best for these plants. The low growing varieties are valuable in the rockery.

alba. Covered with masses of small white flowers in early Summer. Spreads rapidly. 18 in. in height.

filipendulina (Fernleaved Yarrow). An improved variety of this old favorite. A showy, flat head of striking yellow flowers adorns each stalk. $3 \mathrm{ft}$.

millefolium roseum (Rosy Milfoil). Deep cerise flowers somewhat resembling field Yarrow in manner of growth. Handsome, dark green, feathery foliage. Midsummer and Fall. 18 to 24 in.

*tomentosa (Woolly Yarrow). Flat heads of bright yellow flowers nodding above the beautifully cut foliage in June. 12 in.

ACONITUM (Monkshood). Tall, branched perennials with tuberous roots. Hooded flowers with Delphiniumlike foliage, blooming in the late Summer and Autumn. Will do well in full sunlight, but the plants bloom longer in the shade. Soil should be rich.

fischeri. Charming deep blue spikes for the Autumn garden. 2 to $3 \mathrm{ft}$. high.

Sparks Variety. The darkest Aconitum. Long period of bloom through Midsummer. 4 to $5 \mathrm{ft}$. $35 \mathrm{c}$. each, $\$ 4.00$ per doz.

wilsoni. A very effective late Fall blooming variety, 5 to $6 \mathrm{ft}$. high, with attractive, violet blue flowers. 50c. each, $\$ 5.00$ per doz.

variegatum (Bicolor). A variety of fischeri with blue and white flowers. $6 \mathrm{ft}$. $35 \mathrm{c}$. each, $\$ 4.00$ per doz.

Plants 25c. each, $\$ 2.50$ per doz., unless otherwise noted 
AETHIONEMA (Stonecress). Shrubs related to Iberis. Thrive best in light, sandy soil, in a dry, sunny location.

*persicum (Lebanon Candytuft). Rock garden or border plant. A shrubby Alpine with deep rose blooms. May to August. 12 to 15 in. $35 \mathrm{c}$. each, $\$ 4.00$ per doz.

AJUGA (Bugleweed). Easily grown in the rock garden or border.

*genevensis. More or less prostrate variety about 8 in. high. Spikes of deep blue flowers.

${ }^{*}$ reptans (Carpet Bugleweed). Rapid spreading plant, more or less prostrate. Blue or purplish flowers. About 6 in.

ALTHAEA (Hollyhock). Best beloved of old fashioned gardens, growing 6 to $8 \mathrm{ft}$. tall. Double. Pink, red, yellow and white.

ALYSSUM (Madwort). An attractive group for the rock garden or border in full sunshine. Ordinary soil.

*argenteum (Yellow Tuft). Silvery foliage. Dwarf and dense growth. Yellow flowers in clustered heads all Summer, beginning to bloom later than Alyssum saxatile. About 15 in. high.

*saxatile (Basket of Gold, Gold Dust, Goldentuft). Bears clusters of tiny golden yellow flowers in May on low stems. Keeps its gray green foliage in excellent condition all Summer. 9 in.

*wulfenianum or montanum. Feathery, silver and gray foliage with light yellow flowers in loose heads. An unusual plant. 35c. each, $\$ 4.00$ per doz.

ANCHUSA (Alkanet, Bugloss). Used in the border for mass effect. Plants do not survive more than three years and should be treated as biennials. Will seed themselves. italica, Dropmore Variety. Clouds of clear, dark blue, small blossoms on tall bushes, 4 to $6 \mathrm{ft}$. high during May and June.

italica, Opal. Similar to above with large, pale blue flowers from June to August.

*myosotidiflora. Sprays of tiny blue flowers, closely resembling Forget-me-nots. 10 to 12 in. 35 c. each, $\$ 4.00$ per doz.; 2 yr. old plants, 50c. each, $\$ 6.00$ per doz.

ANDROSACE (Rock Jasmine). Is particular as to soil conditions. Will not do well in heavy clay or loose, sandy soil. Requires gritty, or stony, soil, and should be protected from Spring rains.

*primuloides. Small tufted clumps. Leaves in rosettes covered with silvery hairs. Pink flowers in clusters. 5 in. 35 c. each, $\$ 4.00$ per doz.

ANEMONE (Windflower). A valuable family for massing or as single specimens. Native varieties generally used in the wild garden or around shrubbery. Need protection from the wind.

canadensis (Canadian or Roundleaved Anemone). Pure white, single flowers from 1 to 2 in. across. Should be planted in a moist spot in full sunlight. May to August. 12 to 18 in. 20c. each, $\$ 2.00$ per doz.

*japonica, Queen Charlotte. One of the most exquisite of the Windflowers, with delicate pink blossoms perched airily on long, slender stems. From August until heavy frost. Requires good drainage. 35c. each, $\$ 4.00$ per doz.

*japonica, Whirlwind. Semi-double, pure white flowers with a golden heart. Needs good drainage. $35 \mathrm{c}$. each, $\$ 4.00$ per doz.

*pulsatilla (Pasqueflower). Delicate lavender forms, suitable for the rock garden. April or May. 9 to 12 in. Requires good drainage. 35c. each, $\$ 4.00$ per doz.

*Syndesmon thalictroides (Rue Anemone). Native. Tuberous-rooted variety. White or pinkish blossoms on slender stems, 4 to $10 \mathrm{in}$. high. The leaves resemble those of the Meadowrue, but smaller. Plant in shade or partial shade. March to early June. 15c. each, $\$ 1.50$ per doz.

ANTHEMIS. Easily grown in any soil. Blooms from Midsummer until frost. kelwayi (Golden Marguerite). Finely cut foliage. Good for cutting.

AQUILEGIA (Columbine). Most graceful and beloved of flowers, needing no introduction. Excellent for cutting. They prefer light, sandy loam, but will do well in most any soil. Not averse to partial shade.

*alpina. A dwarf variety for the rock garden. Biue flowers with incurved spurs. July to August. 10 to 12 in.

Long Spurred Varieties: Yellow (Chrysantha), blue shades, white, pink shades, and Mrs. Scott Elliotts Hybrids (mixed shades and combinations of colors).

Plants 25c. each, $\$ 2.50$ per doz., unless otherwise noted 


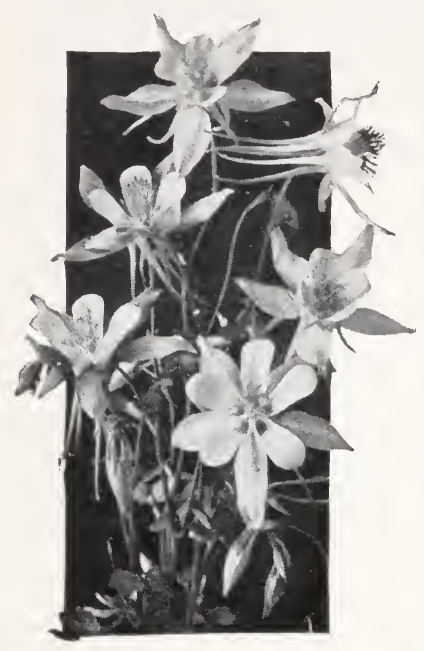

AQUilegia

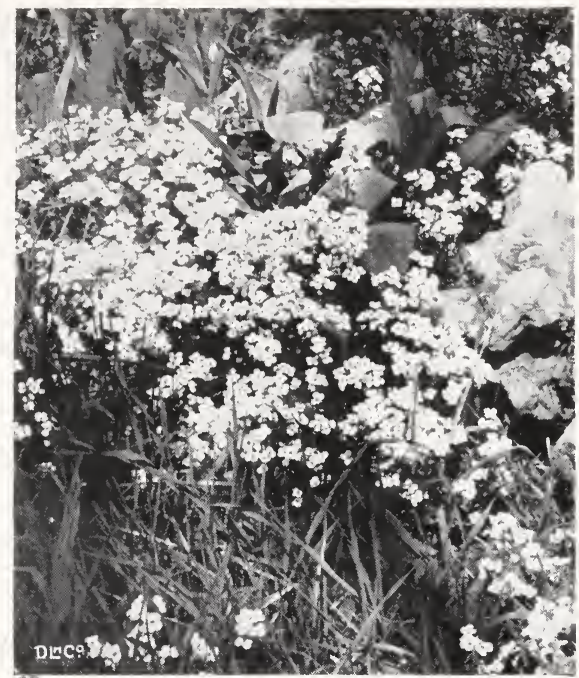

ARABIS

ARABIS (Rockcress). Familiar plants in the rock garden and border. They need sun and good drainage, but will thrive in poor soil. Bloom early in the Spring.

*alpina. Lovely, low mats of grayish serrated foliage all the season, but especially valuable for its little, single, silvery white flowers in abundance in April and May. Fragrant.

*alpina florepleno. Double flowered variety of the above. $35 \mathrm{c}$. each, $\$ 4.00$ per doz.

*rosea. Single pink flowers similar in habit to the above. 35c. each, $\$ 4.00$ per doz.

ARENARIA (Sandwort). Suitable for every type of garden.

*montana. A shiny Spring visitor with white flowers and a mat of low, fine, dark green foliage.

*verna. A tiny, compact rock plant covering the ground like a rich, green moss. Adapted to use in cracks of walks and walls.

ARISAEMA (Jack-in-the-pulpit, Indian Turnip). Native. Needs no description. Moisture and shade are necessary. Flowers from early Spring until June.

triphyllum. Forms a cluster of bright red berries in July, which remain on the stalk after the leaves die down.

ARMERIA (Sea Pink or Thrift). Tufts of evergreen foliage from which spring innumerable flowers borne on wiry stems. The flowers are often cut and dried for use in bouquets. Are happy in any soil.

*formosa. Rosy pink heads on stiff stems, 6 to 8 in. high in Midsummer.

*laucheana. Compact tufts of grasslike foliage. The pink flower heads composed of tiny, individual flowerlets, are supported on fine, stiff stems. 30c. each, $\$ 3.50$ per doz.

*maritima alba. White flowers above tufts of deep green foliage. May to June. 3 to 6 in.

ARTEMISIA (Wormwood). Aromatic herbs or small shrubs. Thrives even in poor soil. abrotanum (Old Man). A soft gray plant from grandmother's gardens. About $2 \mathrm{ft}$. high. Not valuable for its blossoms, but only for fragrance and memories.

lactiflora (Hawthorn Scented Mugwort). Tall, graceful plumes of Hawthorn scented blooms. White, with attractive, dark green, finely cut foliage. Especially valuable for late Summer flowering and for cutting. 4 to $5 \mathrm{ft}$.

Silver King (Ghost Plant). The silvery white leaves and stems of this plant make it valuable as a filler for sprays and bouquets of cut flowers. Can be cut and used without moisture after it matures in early Summer. $3 \mathrm{ft}$.

*stelleriana (Old Woman). Silvery white foliage, deeply cut. Used in the rock garden and in carpet bedding. 18 in.

Plants 25c. each, $\$ 2.50$ per doz., unless otherwise noted 
ASCLEPIAS (Butterflyweed). Of easy cultivation.

*tuberosa. The brilliant orange Wildflower of our July and August fields. 1 to $2 \mathrm{ft}$.

ASPERULA (Woodruff). Members of this family require half shade and moist soil.

*hexaphylla. A delicate, misty spray of white flowers on stems from 1 to $2 \mathrm{ft}$. in length. Used for cutting with Sweet Peas or other flowers that are liable to appear lumpy in bunches. May to July. 50c. each, $\$ 5.00$ per doz.

*odorata. A dainty plant with miniature white flowers of exquisite fragrance in May and June. Its unusually attractive foliage makes it valuable as ground cover. 6 to 8 in. 35 c. each, $\$ 4.00$ per doz.

ASPHODELINE. Used in the border and wild garden. Easy cultivation in any soil. lutea (True Asphodel or Kings Spear). Grassy foliage with Lilylike, yellow blossoms on 3 to $4 \mathrm{ft}$. stems. Blooms from July to September in partial shade, but does best in full sunlight. Fragrant. 30c. each, $\$ 3.00$ per doz.

ASTER, JAPANESE HARDY.

*Mauve Cushion. Soft mauve blossoms with silvery white reflection, entirely covering the plant. Starts to bloom in October, reaching its best in November. A cushionlike plant rarely growing more than 9 in. in height and spreading $2 \mathrm{ft}$. or more across.

ÁSTER (Michaelmas Daisy). Resembling somewhat the purple Aster of Autumn roadsides, and indispensable for the background of the perennial border. We can furnish the following varieties:

Anita Ballard. Light, Lobelia blue with lighter center. Early variety. 3 to $4 \mathrm{ft}$.

Capitaine. Light lavender blue. $4 \mathrm{ft}$.

Heather Glow. Rose colored with golden center. $4 \mathrm{ft}$. 35 c. each, $\$ 4.00$ per doz.

Maid of Athens. A fine variety of sturdy growth. Clear rose pink. $3 \mathrm{ft}$. 35̃c. each, $\$ 4.00$ per doz.

novibelgi, Climax. Lavender blue. $5 \mathrm{ft}$.

novibelgi, St. Egwin. Rosy pink. 3 to $4 \mathrm{ft}$.

Nurse Cavell. Early rose pink. 3 to $4 \mathrm{ft}$.

October Dawn. Lilac mauve, branching habit. $2 \mathrm{ft}$.

Sam Banham. A fine cutting variety. Large, semi-double flowers. Early flowering. The best of the white varieties. 3 to $4 \mathrm{ft}$.

ASTER, HARDY. Species. Many of these are excellent for cutting. Used in rock gardens and front of the border.

*alpinus (Rock Aster). Bluish purple flowers, 6 to 10 in. high, in May and June. For the rock garden or border.

*subcaeruleus. Pale blue Daisy with yellow center. Slender stems about $1 \mathrm{ft}$. high.

tataricus. An attractive variety from Siberia. Grows to $7 \mathrm{ft}$. high. Flowers blue or purple. Fall blooming.

ASTILBE (Spiraea). This family prefers a half shady location, rather moist, in any garden soil. The plants produce many branched heads of feathery flowers in June and July.

alba. An old fashioned, very hardy variety with fine, soft, white blossoms. July and August. 3 to $4 \mathrm{ft}$.

*filipendula hexapetala (Dropwort). Creamy white flowers in large clusters in May-June. 18 in. 30c. each, $\$ 3.00$ per doz.

Metta Imink. An unusually beautiful pink Spirea for the Midsummer garden. $3 \mathrm{ft}$. 50c. each.

AUBRIETIA. The attractive foliage covers the ground and tumbles over rocks in a dense mat. In early Spring, the blooms form sheets of exquisite coloring in violet, carmine and rose. An ideal plant for walls and in crevices. Thrives best in a half shady location. *purpurea. Lavender or purple.

*Suttons Rose. Rich rose color. 50c. each.

BAPTISIA (False-indigo). Adapted to the border and wild garden.

australis. Blooms are dark blue, resembling the Sweet Pea in shape and appear in Summer. Interesting foliage. 4 to $6 \mathrm{ft}$.

BOCCONIA (Plume Poppy)

cordata. Tall, decorative plants about $6 \mathrm{ft}$. high for back part of border. Has interesting leaves, plumelike wands of creamy flowers in Midsummer.

Plants 25c. each, $\$ 2.50$ per doz., unless otherwise noted 


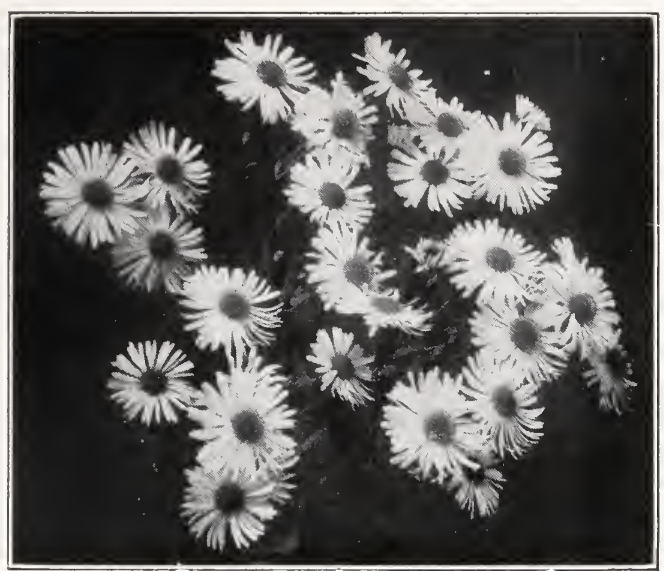

BOLTONIA

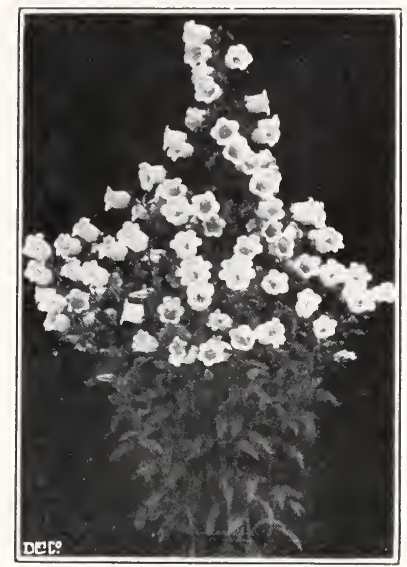

Campanula

BOLTONIA (False-camomile). Resemble wild Asters. For the border or as specimen plants. Do well in any soil.

asteroides. Hundreds of white, Daisylike flowers on sprays 6 to $8 \mathrm{ft}$. in August and September.

latisquama nana. Similar to the above but grows only $3 \mathrm{ft}$. tall and has pink flowers. September.

BUPHTHALMUM (Oxeye). Showy perennials for the border.

cordifolium. Large, decorative leaves with showy, yellow flowers, with brown centers. About $4 \mathrm{ft}$.

salicifolium. A remarkably useful yellow Daisy for August and September. Spreads rapidly. $2 \mathrm{ft}$.

CALAMINTHA (Savory). Aromatic herbs for the rock garden and border.

*alpina (Alpine Savory). Violet blue flowers borne in clusters on a prostrate, rather woody plant, $6 \mathrm{in}$. high. Especially adapted to the dry, sunny conditions of the rock garden.

CAMPANULA (Bellflower). A delightful group of plants varying greatly in form, from the tall, stately variety to the dwarf, compact type. They require rich soil, and the period of bloom may be prolonged by planting in partial shade.

* carpatica (Carpathian Harebell). Grows about 8 in. high in compact tufts and is especially adapted to the rock garden and edges of hardy borders. Lavender blue bells throughout Midsummer.

* carpatica alba. A white flowered variety of the above.

glomerata (Clustered Bellflower). Clusters of clear purple, funnel shaped flowers. June to August. 18 in.

medium (Canterbury-bells). A biennial, but its appealing form and coloring are needed in the June garden. Pink, blue and white.

*Native variety. Light blue bells in Midsummer. About $2 \mathrm{ft}$.

persicifolia grandiflora, Blue (Peachbells). One of the finest of this family, with large blue, cup shaped blossoms in June and July. $2 \mathrm{ft}$.

* portenschlagiana, or muralis. The shiny leaves are surmounted by clouds of blue flowers on slightly longer stems. 6 to 9 in. 35 c. each, $\$ 4.00$ per doz.

*pusilla. Very dwarf. Quickly forms dense mats of shining leaves. The nodding blue flowers appear from June to October. 50c. each, $\$ 5.00$ per doz.

pyramidalis (Chimney Bellflower). One of the most attractive members of this charming family. Large, porcelain blue flowers crowning a perfect pyramid of foliage. August. 4 to $6 \mathrm{ft}$.

*rotundifolia (Bluebells of Scotland, or Harebells). Clear blue flowers on tall, slender stems. Very graceful in the rock garden. June and July. 6 in. 35c. each, $\$ 4.00$ per doz.

Plants 25c. each, $\$ 2.50$ per doz., unless otherwise noted 
CATANANCHE (Cupids-dart). Does well in ordinary soil.

*caerulea. A blue Daisylike flower on slender stems about $2 \mathrm{ft}$. high. Used by the ancient Greeks in making love philters, but now often used as everlastings. Blooms June to August.

CENTAUREA (Hardheads or Knapweed). Free blooming plants for the border and excellent for cutting. Grow vigorously in any soil.

dealbata. Bright rose colored flowers of Cornflower shape. July to September. $2 \mathrm{ft}$. macrocephala. Yellow heads sometimes $4 \mathrm{in}$. across and resembling thistles in shape. $3 \mathrm{ft}$.

montana (Mountain Blurt or Hardy Cornflower). The blossoms are similar to the annual Cornflower but much larger. Blue in color. July to September. $2 \mathrm{ft}$.

CENTRANTHUS (Valerian). Flourishes in ordinary garden soil but will Winterkill if drainage is poor.

ruber (Red Valerian). A handsome plant familiar to the gardens of long ago, now much neglected. Fragrant, cerise blooms throughout Summer. About $2 \mathrm{ft}$.

albus. A variety of the above with white blooms. $2 \mathrm{ft}$.

CERASTIUM (Mouse-ear, Chickweed). Used in the rock garden, border, and for bedding. Easily grown under ordinary conditions.

*tomentosum (Snow-in-summer). Forms creeping masses of tiny, gray leaves all the year. Rather large white flowers cover the entire plant in early Summer. About 6 in.

CHEIRANTHUS (Wallflower). Sunny, well drained soil conditions are essential. Most of the Wallflowers are not hardy in this section.

allioni (Siberian Wallflower). Should be treated as a biennial. An exquisitely brilliant orange addition to the Spring and Summer border or rockery. Dwarf and compact. About 20 in.

CHELONE (Turtlehead). Allied to the Pentstemon. Easily grown plants which do best in partial shade. Should not be planted in dry ground. In the ordinary border it is advisable to mulch with 4 or 5 in. of well rotted manure during their growing season in order to avoid drying out.

barbata torreyi. Handsome spikes of coral pink flowers for Summer and Fall garden About $2 \mathrm{ft}$.

obliqua. A stately, upright habit of growth with rose blossoms. About $2 \mathrm{ft}$. 35c. each, $\$ 4.00$ per doz.

CHRYSANTHEMUM. For Autumn blooms. Should be planted in full sunshine and location must not be wet or plants will not survive the Winter. We have in stock the following excellent varieties but can secure for you almost any variety you desire.

Angelo. Old fashioned, large flowered sort. Light pink.

Bronze Button. Medium height and late flowering. Very hardy and increases rapidly Bronze flowers of tiny, buttonlike shape, in large heads. $3 \mathrm{ft}$.

Chrysolora. Early yellow, large, incurved.

Cometo. Early, large, pink button.

Firelight. Early, aster type, bright red.

Idolf. Very early, Aster type, salmon pink.

Lillian Doty. Medium early, ball shaped, light rose.

Mrs. F. H. Bergen. Midseason, Aster type, light pink.

Mrs. H. Harrison. Early, button type, pale pink.

Mrs. Henry F. Vincent. Fawn and bronze with salmon pink. Flowers well. Erect grower. Medium.

Skibo. Midseason, small button, yellow.

Yellow Normandy. Earliest yellow to come into flower. Large.

CHRYSANTHEMUM maximum (Shasta Daisy). It is best to treat this group as biennials, being short lived perennials.

Alaska. Large blooms in June and July. About $2 \mathrm{ft}$. Resembling the wild white Daisy but larger and finer.

leucanthemum florepleno. Double white flowers in June and July. Valuable for cutting and an unusual flower. $2 \mathrm{ft}$.

CONVALLARIA (Lily-of-the-valley).

majalis. Splendid for massing in shady places. Responds to good treatment. Fragrant white flowers in May and June. Clumps, 50c. each, $\$ 5.00$ per doz.

COREOPSIS (Tickseed). For the garden and border. Is content in any soil.

lanceolata. Golden flowers on long stems throughout Summer. Fine for cutting. $2 \mathrm{ft}$.

Plants 25c. each, $\$ 2.50$ per doz., unless otherwise noted 
COTYLEDON. A rock garden plant enjoying the same conditions as Sedum and

Sempervivum.

*simplicifolium. Deep yellow flowers, dropping gracefully. About 6 in.

CRUCIANELLA (Crosswort). Of easy cultivation in rock garden or edging of border. Does well in full sunlight but prefers partial shade.

*stylosa. Hardy, prostrate perennial forming mats. The early blooming flowers are deep rose, $1 / 2$ in. across. 6 in.

DELPHINIUM (Larkspur). One of the loveliest of cultivated plants and thrives in any good garden soil. Sprinkling of lime or sifted coal ashes around the plants protects them from slugs, and a light covering of coal ashes over the crowns is helpful during the Winter where the soil is wet. After the first bloom is gone cut off the flower stems close to the ground and the new shoots will give a second bloom. If this method is followed, a succession of bloom may be produced from Spring until frost,but the later bloom is rarely as abundant as the first. Best results are obtained when grown in full sunlight, but we have had very pleasing results where the plants received only morning or afternoon sun. All the Delphiniums are fine for cutting.

Belladonna. Has no equal for exquisite light blue coloring and delicacy of form. Blooms throughout Summer and early Fall.

Bellamosum. The same branching spires as Belladonna, but clear, deep blue in coloring. Summer and early Fall.

Hybrids. A remarkably sturdy type, embracing all shades from palest blues and mauves to deep Oxford blue and purple.

*chinense (Blue Butterfly). A dainty little Delphinium with finely cut foliage and a wealth of dark blue spires throughout the Summer. About 18 in. high.

*chinense. Another form of the Blue Butterfly, but with entrancing white flowers with green dots on the back of each petal. A very constant little bloomer.

DESMODIUM (Tick Trefoil). A useful border plant. Ordinary soil.

penduliflorum. A sub-shrub, strikingly attractive with its rosy purple blossoms in September and October. About $5 \mathrm{ft}$. 35c. each, $\$ 4.00$ per doz.

DIANTHUS (Pink). A very large family of evergreen plants, mostly tufted or mat forming, and many are fragrant. Some varieties should be replaced after about three years. The mat forming varieties may become stringy and unsightly looking, but can be rejuvenated by cutting back the long growth close to the base. Removing the dead blooms before seeding by cutting off the stems close to the ground is beneficial to all varieties. They do well in any soil but need full sunlight.

*alpinus allwoodi. A new one and one of the finest for the rock garden. Large, brilliant rose colored flowers above the glossy leaves in June and July. 6 in. $50 \mathrm{c}$. each, $\$ 5.00$ per doz.

*arenarius (Sandloving Pink). Heavily fringed white flowers with delicious fragrance. 6 to 8 in. high, blooming July to September. Does best in sandy soil.

*barbatus (Sweet-william), Newport Pink. A clear pink variety of the beloved Sweet-william of old-fashioned gardens. June and July. 1 to $2 \mathrm{ft}$.

* caesius (Cheddar Pink). One of the very loveliest of the Dianthus family. Compact, grayish tufts of foliage about 3 to 4 in. high, with sheets of pale pink flowers borne on taller stems during the early Summer.

*deltoides (Maiden Pink). Hundreds of joyous miniature pinks on every plant. Very vivid and arresting. Bright pink and blooming all Summer.

neglectus. Very dwarf, brilliant cherry salmon flowers. Grasslike leaves. One of the loveliest of Pinks. Requires gritty or stony soil, 6 in. high. 40c. each, $\$ 4.40$ per doz.

*plumarius (Spice Pink). Assorted pinks, single and double, covered with blooms and filling the June garden with spicy fragrance.

*plumarius nanus. A compact, tidy variety of the above.

DICENTRA. Thrives in light soil, well fertilized, in full sunlight or in partial shade.

*cucullaria (Dutchmans-breeches). A very early Spring flower, white tipped yellow. The nodding blossoms resemble pairs of breeches hung upside down. Grows in full or partial shade. The leaves are exquisitely shaped and attractive. About 6 in. $15 \mathrm{c}$. each, $\$ 1.50$ per doz.

*formosa (Plumy Bleedingheart). A dwarf variety with finely cut foliage. Small pink flowers from April to August. About 18 in. 30c. each, $\$ 3.50$ per doz.

spectabilis or Dielytra spectabilis (Bleedingheart). Soft pink, heart-shaped flowers on graceful, bending stems. This is one of the most exquisite early Spring visitors ever introduced into our gardens. Blooms with the Tulip, Narcissus and Mertensia. 2 to $3 \mathrm{ft}$. $50 \mathrm{c}$. each.

Plants 25c. each, $\$ 2.50$ per doz., unless otherwise noted 
DICTAMNUS (Gasplant or Burning Bush). Thrives in rich, heavy soil.

fraxinella rubra. A long-lived variety with attractive, rose pink flowers. 2-year-old plants, 35c. each, $\$ 4.00$ per doz.

DORONICUM (Leopardbane). Average garden soil conditions.

*caucasicum. One of the most effective early blooming perennials and excellent for cutting. Large, yellow, Daisylike flowers, very effective in masses. 35c. each, $\$ 3.50$ per doz.

ECHINOPS (Globethistle). Used in the border for striking effects. The plants are erect and bold appearing. Ordinary culture in the open.

ritro (Small Globethistle). Odd metallic blue spikes or balls for flowers carried on stems 2 to $3 \mathrm{ft}$. in height. Pretty thistlelike foliage. For the Midsummer garden.

sphaerocephalus (Great Globethistle). Similar to the above, but growing 5 to $8 \mathrm{ft}$. high. Two varieties with blue or white flowers.

ERICA (Heath). Evergreen, branchy shrubs with profuse bloom. Light or sandy soil, free from lime is essential. We offer varieties hardy as far north as Central New England.

carnea. A particularly adaptable and charming plant for the rock garden, with its deep green foliage and nodding red bells. 12 in. 60c. each, $\$ 7.00$ per doz.

*vulgaris (Heather). A true Scotch Heather. The beauty of its rose color is ably described in song and verse. Blooms profusely in late Summer. Generally about 18 in. high but sometimes grows to $3 \mathrm{ft}$. 60c. each, $\$ 7.00$ per doz.

*vulgaris aurea. Dwarf variety of the above with golden leaves. 60c. each, $\$ 7.00$ per doz.

ERINUS. A tufted plant native to the mountains of western and central Europe. Should be planted in partial shade and where the drainage is unusually good.

*alpinus albus. Racemes of white flowers with rosettes of foliage make this a valuable addition to the rock garden. 4 in. 35 c. each, $\$ 4.00$ per doz.

*alpinus roseus. Similar to the above with rosy purple flowers.

ER YNGIUM (Eryngo). Sunny position in rock garden and border. Light rich soil preferred.

*amethystinum (Seaholly). Round, thistlelike heads of amethystine blue with very finely cut foliage. July to September. 2 to $3 \mathrm{ft}$

ER YSIMUM (Blistercress). This group of plants is related to the Wallflower and Stock families. Require full sunlight and good drainage.

*pulchellum (Fairy Wallflower). A splendid rock plant growing about 6 in. high. Covered in the Spring with bright yellow flowers. 30c. each, $\$ 3.50$ per doz.

EUPATORIUM (Thoroughwort or Boneset). Thrives under ordinary garden conditions. *coelestinum (Mistflower). Fluffy, lavender, Ageratumlike blossoms late in the Summer until heavy frost. 2 to $3 \mathrm{ft}$. high.

EUPHORBIA (Spurge). Plant in good garden soil in the border or rock garden. corollata. A valuable plant for cutting and its small, pure white flowers take the place of Gypsophila paniculata when the latter is gone. August-September. 18 to 24 in.

*polychroma (Wolfs Head). Attractive foliage covered with yellow, flowerlike bracts in May. The bracts changing to a soft green later in the season. $2 \mathrm{ft}$.

FESTUCA (Fescue). Requires no special conditions.

*glauca (Blue Fescue). An attractive, tufted, blue green grass with glaucous foliage. Forms neat clumps which are attractive in the border or rock garden

FUNKIA (Plantainlily). Used extensively for borders and thrives in sun or shade. The abundant foliage is always attractive. Flowers are bell-like, on graceful, long stems. July and August.

caerulea lanceolata. Blue flowers and broad green leaves. About 18 in.

lancifolia. Dull green leaves, long and narrow. Lilac blue flowers. About 18 in.

minor (Dwarf Plantainlily). White flowers in August and September. 8 in. 40c. each, $\$ 4.50$ per doz.

variegata. Leaves variegated green and white. Blue flowers. About 18 in.

Plants 25c. each, $\$ 2.50$ per doz., unless otherwise noted 


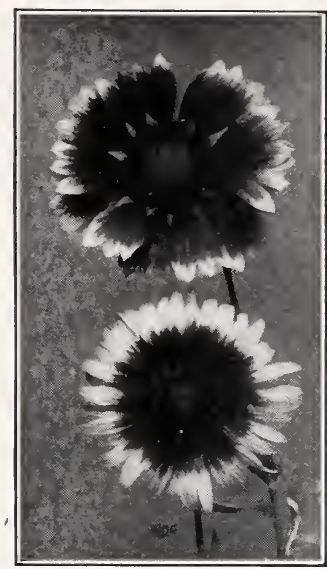

Gaillardia

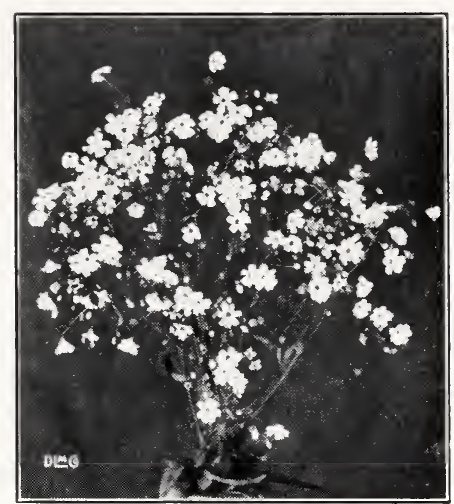

GYPSOPHILA

GAILLARDIA (Blanketflower). Cannot be excelled for cut flowers. Requirements are full sunlight and light, open, well drained soil. Blooms from June to November and will stand almost any amount of dry weather.

Burgundy. Large, shining, wine red flowers, sometimes more than $2 \mathrm{in}$. in diameter, on long, stiff stems. $2 \mathrm{ft}$.

Giant Hybrids. Very large blossom of henna red and orange or yellow in one flower. Gives life and brilliance to the garden. 1 to $2 \mathrm{ft}$.

The Dazzler. Bright golden flowers with red maroon centers on straight, erect stems. A recent introduction and the best of the family. 35c. each, $\$ 4.00$ per doz.

GAULTHERIA.

*procumbens (Wintergreen, Checkerberry, Teaberry). Creeping plant with white flowers nodding above the shiny, evergreen leaves. Aromatic odor. Scarlet berries follow the blossoms and remain until the following season. Requires partial shade and acid soil. June to September. 30c. each, $\$ 3.00$ per doz.

GAURA. Native herbs of easy culture in the border or wild garden.

lindheimeri. Loose terminal spikes of white flowers. Graceful and attractive. 3 to $4 \mathrm{ft}$.

GENTIANA (Gentian). Grown generally in rock gardens but may be used in the garden where conditions are right. Requirements are good drainage, plenty of moisture, and shade.

*andrewsi (Closed or Bottle Gentian). Beloved native of our woods and fields. Clusters of bluish purple flowers in the Fall. About 10 in. high.

GEUM. Rock garden and border plants. Easy culture.

*coccineum, Mrs. J. Bradshaw. A new variety with striking Chinese red, double flowers. Blooms greater part of Summer. $2 \mathrm{ft}$.

*Lady Stratheden. Similar to the above with double flowers of rich golden yellow.

*Orange Queen. Intermediate between the above two varieties. Flowers of brilliant coloring, some showing combinations of yellow and red. Summer to Autumn. $2 \mathrm{ft}$.

GYPSOPHILA (Babysbreath). These plants have scant foliage when in blossom. Their habit of growth is very branchy or spreading, and make excellent covering for bare spaces or among shrubbery. Useful in bunches of cut flowers.

*cerastioides. An excellent rock garden plant of creeping habit. Flowers are white or lilac, pink veined and of large size. 3 in. high. $35 \mathrm{c}$. each, $\$ 4.00$ per doz.

paniculata (Babysbreath). Masses of tiny, misty white flowers on slender stems. Valuable for cutting. July and August. 2 to $3 \mathrm{ft}$.

*repens (Creeping Babysbreath). A small, trailing rock garden plant with tiny Babysbreath blossoms through July and August.

*repens rosea. A pink flowered form of the above.

Plants 25c. each, $\$ 2.50$ per doz., unless otherwise noted 
HELENIUM (Sneezewort). Native. Sunny position in rich soil in the wild garden or back part of the border.

autumnale rubrum. A glorious henna red plant of the Aster type for Autumn garden. 3 to $4 \mathrm{ft}$. Plant with the Michaelmas Daisy.

autumnale superbum. Clear golden form of the above.

hoopesi. Rather long leaves, oblong in shape. The flowers resemble large yellow Daisies and are borne in several heads on long, stiff stems. June. $3 \mathrm{ft}$.

*HELIANTHEMUM (Rock or Sunrose). Evergreen plants forming low, broad clumps. From July to September are hidden by a mass of bloom. Suitable for the rock garden or border, but require good drainage.

croceum. Single yellow. 35c. each, $\$ 4.00$ per doz.

Double Orange. $35 \mathrm{c}$. each, $\$ 4.00$ per doz.

Fireball. Double, bright scarlet. 35c. each, $\$ 4.00$ per doz.

Mixed. Single, pink and white. 35c. each, $\$ 4.00$ per doz.

Mrs. Earle. Single, scarlet. 35c. each, $\$ 4.00$ per doz.

praecox. Silvery foliage with single yellow flowers. 35c. each, $\$ 4.00$ per doz.

HEMEROCALLIS (Daylily). Easily grown in any good garden soil. Spread rapidly and make an excellent ground cover.

flava (Tall Yellow Daylily). Fragrant yellow Lily; narrow pointed leaves. Spring. $3 \mathrm{ft}$. fulva kwanso. Late Summer blooming variety; double, rusty orange red flowers. $3 \mathrm{ft}$. middendorffi (Broad Dwarf Daylily). The earliest variety, blooming in the Spring. Flowers are pale orange in a close cluster or head. About 18 in.

thunbergi (Late Yellow Daylily). Lemon yellow flowers in Summer. Slightly fragrant. About $3 \mathrm{ft}$.

HEPATICA (Liverleaf). Shade or partial shade and rich, well drained soil are essential

*triloba (Roundleaved Hepatica). Native. The flowers which are lavender blue to pink and white, appear before the three-lobed leaves in early Spring. 20c. each, $\$ 2.00$ per doz.

HESPERIS (Rocket) Ordinary garden conditions. Should be treated as a biennial in the Border or Wild Garden.

*matronalis (Sweet Rocket). Dwarf delicate mauve. A new variety of English origin. The blooms of delicate bluish-mauve in early Spring are sweetly scented. 15 in. high.

HEUCHERA (Alum-root). Native. For the border, rock garden and wild garden. Thrive in average garden soil in the open or in partial shade.

*brizoides. Tiny, deep pink bells on daintily swaying stems carried well above the foliage make this an unique Summer plant. About 18 in. 35c. each, $\$ 4.00$ per doz.

*sanguinea (Coralbells). Similar to the above but coral red in color. $35 \mathrm{c}$. each, $\$ 4.00$ per doz.

HIERACIUM (Hawkweed). Rapidly spreading plants in the garden or rock garden. They thrive in poor soil and care must be used to prevent them spreading too far. aurantiacum (Devils Paintbrush or Orange Hawkweed). A low-growing plant with hairy leaves. The light orange red flowers are borne on slender, hairy, leafless stems, 6 to 20 in. long. Blooms from June to September.

villosum. A desirable garden plant with its large golden flowers and silvery foliage. June to August. 1 to $2 \mathrm{ft}$.

HYPERICUM (St. Johnswort). Easy cultivation.

*olympicum. A rare rock plant with gray foliage and large yellow flowers. June-July. 6 in. 35 c. each, $\$ 4.00$ per doz.

IBERIS (Candytuft). Evergreen perennials, somewhat woody at the base, low and compact. Useful for edging and in the border and wall garden. No special treatment and do well in average garden soil. Flowers generally white but sometimes turning lilac with age.

*sempervirens (Hardy or Edging Candytuft). Small plant with fine leaves and bearing countless clusters of dazzling white flowers in early Summer. The oldfashioned variety commonly used for edging walks. drives and borders. About12 in.

*sempervirens, Little Gem. A dainty variety and very dwarf. Completely covered with tiny white flowers. 6 in.

*sempervirens, Snowflake. A new variety with large heads of white blossoms. About 12 in.

*gibraltarica (Gibraltar Candytuft). Lilac flowers in flat or nearly flat heads. 12 in.

Plants 25c. each, $\$ 2.50$ per doz., unless otherwise noted 
INULA (Fleabane). Average garden soil and plenty of sunlight.

*ensifolia. Bright yellow flowers cover the compact, symmetrical clumps of foliage in July. $1 \mathrm{ft}$.

LATHYRUS. Any soil.

latifolius (Perennial or Everlasting Pea). A perennial vine climbing to $9 \mathrm{ft}$. Used for covering walls, fences, or unsightly places. Large, rose colored flowers similar in shape to the Sweet Pea.

latifolius albus. Similar to the above but pure white.

LAVANDULA (Lavender). Plants of this genus require good drainage and protection during the Winter in the North.

stoechas. Dark purple flowers in dense spikes with tufts of large purple bracts. $3 \mathrm{ft}$. 35 c. each, $\$ 4.00$ per doz.

*vera (Sweet Lavender). The fragrant flower of romance and bygone ages. The Summer blossoms should be picked and dried. 12 to $14 \mathrm{in.}$

LEONTOPODIUM alpinum (Edelweiss). Small yellow flowers surrounded by woolly leaves in starlike form. The leaves are white. Requires deep sandy or gritty soil as the roots are long. June to August. 4 to 5 in. $50 \mathrm{c}$. each, $\$ 5.00$ per doz.

LIATRIS (Blazing-star or Button Snakeroot). Native. Place it in the border or wild garden. Average garden conditions will keep it thriving.

pycnostachya. Rosy purple blooms on long, sturdy stems. July to August. 4 to $6 \mathrm{ft}$.

LILIUM (Lily). Bloom in the late Spring and Summer. A sandy or loamy soil, light and fertile is best for them. Leafmold should be added. They do best in partial shade. A handful of sand or gravel should be placed under each bulb when planting. Remove seed pods immediately after flowering.

canadense (Meadow Lily). Native. Drooping flowers orange yellow to red, spotted purplish brown. 3 to $5 \mathrm{ft}$.

candidum (Madonna Lily). The fragrant white Lily of the Annunciation and the June garden. $3 \mathrm{ft}$. Bulbs, 50c. and $60 \mathrm{c}$. each, $\$ 5.00$ and $\$ 6.00$ per doz.

philadelphicum (Orangecup Lily). Native. About $2 \mathrm{ft}$. high with one or two upright, open flowers. Orange red spotted purple. 40c. each, $\$ 4.00$ per doz.

speciosum magnificum. Most popular of the Midsummer Lilies. Pinkish with crimson spots. $3 \mathrm{ft}$. or more. Bulbs, $50 \mathrm{c}$. each, $\$ 5.00$ per doz.

tigrinum (Tiger Lily). Old fashioned orange Lily with curled petals and many black freckles. Very decorative for Midsummer. 3 to $4 \mathrm{ft}$. Bulbs, $40 \mathrm{c}$. each, $\$ 4.00$ per doz.

LINARIA (Toadflax). Of easy culture. Not hardy in the North, but seed themselves. Plant in moist, half shady positions.

*cymbalaria (Kenilworth-ivy). Tiny leaves and small lavender flowers with attractive vining habit. Used for hanging baskets, window boxes and rockery.

*hepaticaefolia. A good Alpine for the rock garden. Makes a very low mat. The little flowers are lilac blue. 35c. each, $\$ 4.00$ per doz.

LINUM (Flax). Desirable plants of easy culture for the border or rock garden.

* flavum (Golden Flax). A yellow form of sturdy growth with broad, flat leaves. $2 \mathrm{ft}$.

*perenne (Blue Flax). A feathery, fragile looking plant with fascinating habits of growth and endurance. Bears clear blue flowers all Summer. 12 to 18 in.

LOBELIA. Do well in any ordinary garden soil but must be kept moist.

siphilitica (Great Lobelia). One of our native Lobelia with large spikes of blue blossoms from July to September. Prefers a damp situation. 2 to $3 \mathrm{ft}$.

LUPINUS (Lupine). Will thrive in poor soils, but must have good drainage. They cannot endure dry weather and must be kept watered during our occasional droughts.

*polyphyllus. Tall. stately spires arising from clumps of oddly, artistically shaped leaves. Early Summer. Lavender, pink and white.

LYCHNIS (Campion). Easily grown.

*alpina (Arctic Campion). A tiny, pink gem for the Spring rock garden, with fine, grasslike foliage. 4 to 5 in.

chalcedonica (Maltese Cross). Clusters of bright scarlet flowers from the old fashioned garden. June and July. $2 \mathrm{ft}$.

LYTHRUM (Loosestrife). Need moist soil and are generally planted in the border and wild garden. Will thrive in partial shade.

salicaria roseum superbum. Native. Handsome, bushy plants with many spikes of deep, rose flowers from July to frost. 2 to $3 \mathrm{ft}$.

Plants 25c. each, $\$ 2.50$ per doz., unless otherwise noted 
MAZUS. Easily grown matting herbs used in the rock garden and for ground cover.

*rugosus. Trailing perennial making dense mat. Blue flowers with the lower lip spotted brown. Early Spring. 4 in. 40 c. each, $\$ 4.50$ per doz.

MENTHA (Mint). Aromatic herbs of easy culture, some needing restraint.

${ }^{*}$ requieni. Forms a dark green carpet of peppermint scented foliage. Flowers mauve or pale purple. Used in the rock garden and for ground cover.

MERTENSIA (Bluebells). Prefers shade.

*virginica (Virginia Cowslip). The very early, exquisite, bluebells of our riversides. Quite hardy in our Spring gardens, and very much needed on account of its perfect blue color and fairylike habits. 18 in. high.

MONARDA (Horsemint). Native. Striking plants for wild garden or border. Of easy cultivation.

didyma (Beebalm or Bergamot). Crimson, old fashioned garden plant with fragrant leaves. 3 to $4 \mathrm{ft}$., blooming in Midsummer. Very decorative in masses.

fistulosa mollis, Lilac. Similar to the above, with lilac flowers.

MYOSOTIS (Forget-me-not). Place in a moist spot in partial shade. Some protection in the Winter is desirable.

*semperflorens. A lovely, clear blue variety, blossoming from Spring until Fall. 8 to 10 in.

NEPETA. Aromatic herbs of simple culture.

*glechoma variegata (Ground Ivy or Field Balm). A creeping variety forming a mat with variegated foliage, green and white. Frequently used as a ground cover Does equally well in sun or shade. Light blue flowers from March to June.

${ }^{*}$ mussini (Catmint). A quickly spreading, dainty, low plant with clouds of misty lavender flowers all Spring and Summer. For borders, rockery and wall gardens. 8 to 10 in. high.

OENOTHERA (Evening-primrose). Dry land plants which must have full sunlight. Easily grown.

*fruticosa youngi. Buttercup yellow flowers, 2 in. across, on a strong and stocky plant. A profuse bloomer. 18 in.

*missouriensis. Large yellow blooms, 4 to 6 in. across, and fragrant. About 12 in.

ONOSMA. Border and rock garden plant.

*stellulatum (Golden Drop). An unusual plant grown for its pretty, tubular golden flowers. About 8 in. 50c. each, $\$ 5.00$ per doz.

PACHYSANDRA. The finest grourd cover for shady places.

terminalis (Japanese Pachysandra or Spurge). A low, creeping evergreen with glossy leaves. Used as a ground cover around foundation planting or among evergreen trees. Will grow in dense shade. 6 to 8 in.

PAPAVER (Poppy). Do well in any soil. Should be planted before the first of May or in the Fall.

*alpinum. A tiny, delicate appearing Poppy resembling the Iceland Poppy. Pink, yellow, orange and white flowers. 4 in. $35 \mathrm{c}$. each, $\$ 4.00$ per doz.

*nudicaule (Iceland Poppy). Fernlike in tufts. The yellow, orange, white, or pink flowers are borne on tall, leafless stems. Blooms throughout the season. 35c. each, $\$ 4.00$ per doz.

orientale (Oriental Poppy). Large scarlet flowers with black markings at base of petals. A brilliant addition to any garden. 35c. each, \$4.00 per doz.

*orientale, Mrs. Perry. Soft salmon rose blooms in June on $2 \mathrm{ft}$. stems. 35c. each, $\$ 4.00$ per doz.

PARDANTHUS. Easy to grow.

chinensis (Blackberry Lily). Little, I,ily-shaped flowers, bright orange in color, with brownish purple spots, followed by Blackberrylike pods. $2 \mathrm{ft}$.

Plants 25c. each, $\$ 2.50$ per doz., unless otherwise noted 


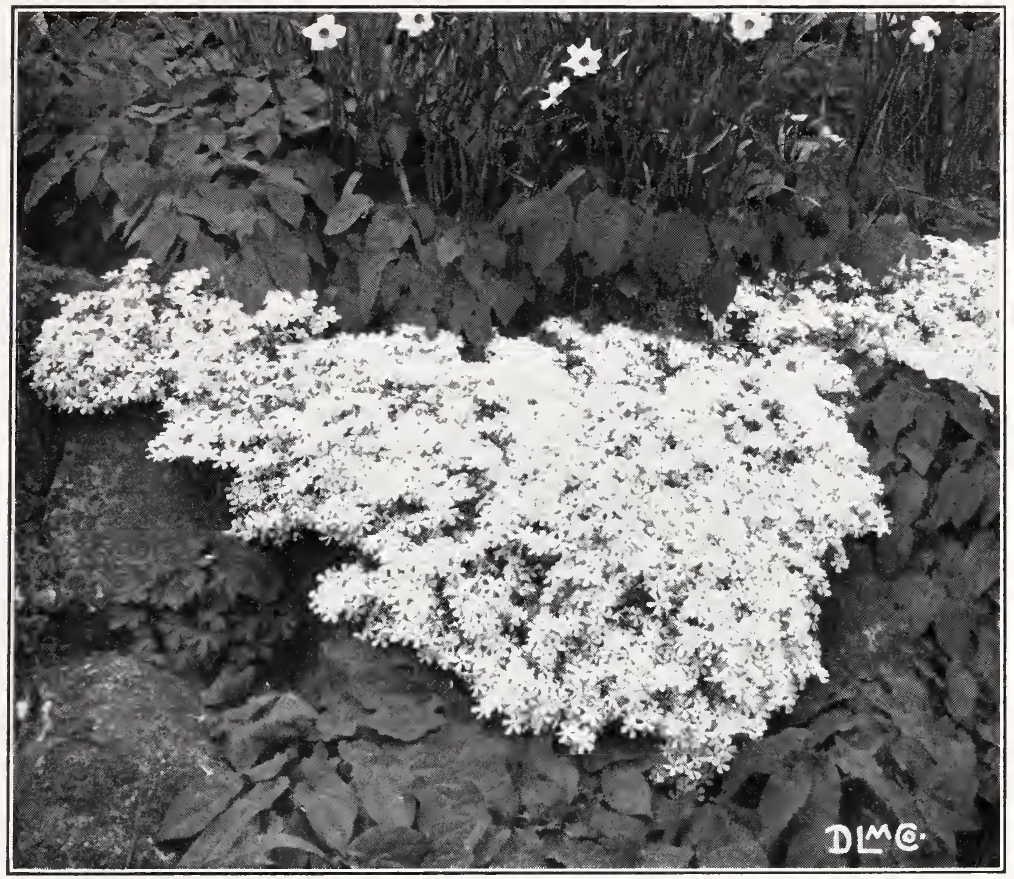

Phlox subulata

PHLOX decussata (Hardy Phlox). Phlox should never be allowed to go to seed and should be divided every three years to prevent change in color. Drought is fatal to these plants. See that they have fertile soil and plenty of water.

Beacon. Cherry red. Tall variety.

Enchantress. A clear salmon pink with deeper eye. We recommend this Phlox in place of Elizabeth Camphell on account of hardiness and sturdier habit of growth. About $3 \mathrm{ft}$.

Europa. White with red eye. Large heads. Medium.

Jules Sandeau. Rather dwarf with many large, deep pink flowers. 18 to $24 \mathrm{in}$. Louise Abbema. Very dwarf. Large, pure white flowers.

Miss Lingard. An early white with dark, shiny leaves. Tall.

Mrs. Jenkins. An excellent white variety. Very early. Medium height.

Rheinlander. Another good pink with deep pink eye. 2 to $3 \mathrm{ft}$.

Thor. Deep salmon pink. Medium height.

Wanadis. Large clusters of violet flowers with purple eye. Medium.

PHLOX divaricata (Blue Phlox).

*canadensis. Lovely light blue blossoms in May to harmonize with the Tulips. 18 in.

*linnaeus (Wild Blue Phlox). The blue flowers are fragrant. Not as tall as Canadensis. Spring. 8 to 10 in.

*PHLOX subulata (Ground or Moss Pink). A tiny, creeping Phlox forming dense mats. Mosslike, evergreen foliage hidden in April and May by a sheet of bloom. Is suitable for border banks, rock garden, or for covering graves. 4 to 6 in.

alba. A white variety.

Appleblossom. A beautiful variety of exquisite color. 35c. each, $\$ 4.00$ per doz. lilacina. Lilac blue.

rosea. Rose pink.

Vivid. One of the finest. Pink with red eye. $35 \mathrm{c}$. each, $\$ 4.00$ per doz.

PHLOX amoena (Lovely Phlox). A charming little Phlox with evergreen foliage, bearing bright pink flowers in Spring. $12 \mathrm{in.}$

Plants 25c. each, $\$ 2.50$ per doz., unless otherwise noted 
PHYSALIS (Groundcherry or Husk Tomato). Need a warm, sunny location.

alkekengi (Chinese Lantern Plant or Winter Cherry). Bright orange scarlet, lantern-

like fruits produced on dense bushes about $2 \mathrm{ft}$. high. Can be cut and dried for

Winter decorations.

PHYSOSTEGIA (False-dragonhead). Native. For the border or wild garden. They are vigorous growing and need a restraining hand.

grandiflora. A new form and valuable owing to its being one of the late flowering dwarf plants. Pink blossoms. August to September. About 18 in.

virginica. Rose pink spikes appearing in great profusion throughout Summer. One of the husky sisterhood, needing elbow room. 3 to $4 \mathrm{ft}$.

PLATYCODON. Flowers resemble those of the Campanula but differ in the opening of the caps. A well drained, sandy loam are the r:ght conditions.

grandiflorum (Balloonflower). June and July bells on stiff stalks, in white or lavender. 2 to $3 \mathrm{ft}$.

*mariesi. A dwarf variety with large purple bells in August. About 10 in. high.

PLUMBAGO (Leadwort). Ordinary garden soil, but Winterkills where drainage is poor. Prefers partial shade.

*larpentae. A most exquisite and valuable little plant quite covered in late Summer and Fall with true blue blossoms. 10 to 12 in.

POLEMONIUM. Easily cultivated in rich loam.

*album (Jacobs Ladder). A plant of tidy and upright growth, carrying quantities of white bells on spikes in early Summer. 18 to 24 in.

*caeruleum. Similar to the above with lavender or purple bells.

*reptans (Greek Valerian). Heavy clusters of delicate looking bells of pale blue to bloom with the Tulips. Extremely attractive foliage lasts all Summer. 10 to 12 in.

POTENTILLA (Cinquefoil). Hardy perennials for the rock garden or border. Any soil. nepalensis, Miss Willmott. A dwarf variety with profuse, rose colored flowers. Midsummer. 8 in.

*PRIMULA (Hardy Primrose). Attractive early Spring blooming plants which require shade and moisture during the hot Summer months. Desirable for planting around shrubbery, trees, and shady nooks in the rockery.

japonica. Mixed colors in white to pink and red. One of the finest Primroses for the garden. 12 to 18 in. $30 \mathrm{c}$. each, $\$ 3.50$ per doz.

vulgaris (The Old English Primrose). Solitary yellow flowers on slim stems. 6 in.

*PRIMULA polyantha (Bunch Primroses). Require rich soil in half-shady position, and appreciate watering during the hot Summer months. Suitable for border, rockery and around shrubbery.

Sutton's Giant White. A free blooming variety with immense heads of large white flowers.

Sutton's Munsted strain. Wonderful shades of yellow, as well as pure white. This strain of Bunch Primroses was brought to perfection in Miss Jeckyll's Garden at Munsted.

veris Hybrids. Various shades of yellow, orange, red and purple blooms on long stems. 6 to 12 in

veris, Duplex. Odd and charming variety known as the Hose-in-hose Primrose. 6 in. $35 \mathrm{c}$. each, $\$ 4.00$ per doz.

PYRETHRUM. Easily grown in ordinary garden soil. Rabbits are very susceptible to their charms and keep them cut off so that they soon disappear.

*Hybrids (Painted Daisy). Tall, graceful Daisies of various shades of pink for the early Summer garden. About $2 \mathrm{ft}$.

uliginosum (Giant Daisy). Small bush in form, literally covered with fine white Daisies. Most valuable for Fall gardens. 3 to $4 \mathrm{ft}$.

RANUNCULUS (Buttercup or Crowfoot). Will grow anywhere and anyhow.

acris florepleno. An upright growing variety with double yellow blooms. A satisfactory flower for cutting. Is best suited in a damp spot in the border.

repens (Creeping Buttercup). A rapid creeping variety with long runners. Yellow single flowers. About 12 in.

RUDBECKIA (Coneflower). Native. Will thrive most anywhere. Generally used in the border or wild garden.

laciniata, Golden Glow. Double Cactus, Dahlialike flowers on 5 to $6 \mathrm{ft}$. stalks. The well known golden flowers bloom from July to September.

purpurea (Purple Coneflower). A plant chiefly interesting for the odd formation of the blooms, the reddish purple petals, $4 \mathrm{in}$. in diameter, resembling those of the Daisy. A brown cone in the center replacing the usual disk. 3 to $4 \mathrm{ft}$.

Plants 25c. each, $\$ 2.50$ per doz., unless otherwise noted 


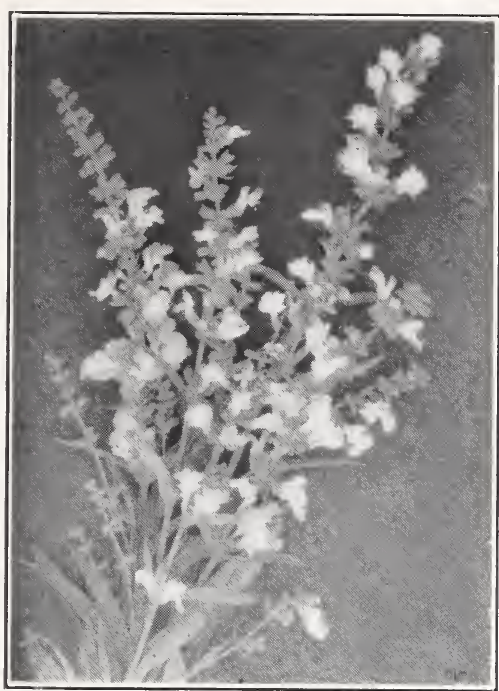

SALVia

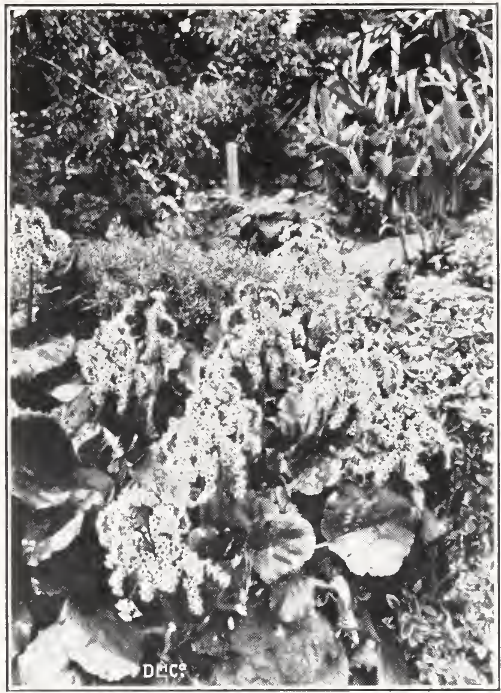

SAXIFRAGA

SALVIA (Sage). A border plant of simple requirements.

azurea (Blue Sage). Sky blue blossoms on many slender, swaying stems suggest coolness and peace for the August garden. 3 to $4 \mathrm{ft}$.

pitcheri. A true blue visitor from Colorado. Particularly valuable on account of its hardiness and length of bloom. August through October. 35c. each, $\$ 4.00$ per doz. pratensis. Large, bushy perennial with wide, rough leaves, bearing dark blue or purplish flowers on $2 \mathrm{ft}$. stalks in June and July.

*SANGUINARIA canadensis (Bloodroot). Well known native perennial with inch wide white flowers. The flowers appear before the large, leathery leaves. Needs shade and rich soil. $15 \mathrm{c}$. each, $\$ 1.50$ per doz.

SANTOLINA. Low, evergreen herbs, or shrubs, with aromatic leaves. Generally used as edging plants.

*incana (Lavender-cotton). Compact and tidy subshrub with silvery gray foliage and small, globular, yellow flowers. The gray foliage makes it an attraction in the rock garden. About 18 in.

SAPONARIA (Soapwort). Any soil will do but avoid planting in a moist location. Border or rock garden.

*ocymoides splendens. A many branched trailing plant with deep rose colored blooms. May to August. About 4 in.

SAXIFRAGA. This group requires a slightly acid soil and semi-shade. Divide every second or third year and they will bloom profusely.

*cordifolia (Rockfoil). A plant of exquisite foliage and most valuable for rock garden or border on account of its early pink flowers. About 12 in. 50c. each.

decipiens (Mossy Saxifrage). A very desirable rock plant with its mossy appearance and green foliage which turns crimson in Winter. White flowers. About 4 in. 50 c. each, $\$ 5.00$ per doz.

decipiens rosea. A pink flowered hybrid similar to the above. 50c. each, $\$ 5.00$ per doz.

sarmentosa (Old Mans Beard or Strawberry Geranium). This variety is hardy in spite of the general contrary belief. It requires acid soil and moisture which may acount for its failure to survive in some locations. A creeping plant with hairy, variegated leaves and white blossoms. 12 to $24 \mathrm{in}$. high. Before frost the largest plants may be potted and brought into the house where they may be used to advantage in the window box or hanging basket. Large plants $\$ 1.00$ each; small plants. 50c. each.

Plants 25c. each, $\$ 2.50$ per doz., unless otherwise noted 
SCABIOSA (Pincushion Flower, Morning Bride). Sunny exposure in any good soil.

*caucasica (Blue Bonnet). Daintily formed flowers of unusual merit born on erect stems. Lavender and white. Midsummer. 18 to 24 in.

japonica (Pincushion Flower). A lavender blue, long stemmed Midsummer flower. 18 to 24 in.

SEDUM (Stonecrop). Indispensable in the rock garden. Most varieties spread rapidly and the splashes of color are most effective. Require sandy soil and full sunshine.

*acre (Golden Moss). A tiny, creeping Sedum with small yellow flowers in early Summer. For rockery, paths and stone walls. 2 to 3 in.

*album (White Stonecrop). A white, little creeper for Spring blooming and a green mat for Summer. 2 to 3 in.

*anglicum. Rose colored flowers with gray, neat, tidy growing foliage. 3 in. $30 \mathrm{c}$. each, $\$ 3.00$ per doz.

*dasyphyllum. Minute gray leaves. Compact growth. Bearing tiny pinkish blooms. The baby of the Sedum family. 2 to 4 in.

*ewersi. Terminating stems, compact rosettes, gray blue in color. 6 in.

*glaucum (Hispanicum minus). An excellent dwarf variety about 2 in. high. Flowers pinkish and white in early Summer. Glaucous blue foliage densely crowded on barren stems.

*kamtschaticum (Orange Stonecrop). Upright growth, bright orange blooms. 6 in.

*lydium. Pink flowers. One of the daintiest of Sedums with bronze green foliage. 2 to 4 in.

*maximowiczi. A heavy growing Sedum with small orange flowers which rapidly cover ground or rocks.

*middendorffianum. Bronze foliage, serrated leaves with brownish yellow flowers. From 4 to 16 in. high. 35c. each, $\$ 4.00$ per doz.

*nevi. Tiny grayish green rosettes in compact mass. Entirely unlike any other Sedum. White flowers. 2 in. 50c. each, $\$ 5.00$ per doz.

*oreganum. The twisted branches terminate with flat, round leaves which redden in the Fall. Resembles a tiny Japanese tree. Yellow flowers. 3 in.

*pruniatum forsterianum. Yellow flowers with glaucous, bluish green leaves. About 4 in. high.

*reflexum. More erect in form than most of the low growing Sedums, 8 to $10 \mathrm{in.} \mathrm{high.}$ A clump of this variety looks like an airplane view of a forest. Yellow flowers in June and July.

*rupestre. Spiny foliage with yellow flowers. About 6 in. Evergreen and easily grown.

*sarmentosum. Yellow flowers. Strong growing habit. About 6 in.

*sexangulare. Similar to Sedum acre but smaller and more compact. Yellow flowers. 4 in.

*sieboldi. An exquisite little rock garden plant 6 to 9 in. high. Gray foliage, pink, fuzzy flowers. August and September.

*spectabile (Showy Sedum). An erect growing variety of Sedum with flat heads of clear pink in August and September. About 12 in. high.

*stoloniferum (Running Stonecrop). Flat, fleshy leaves with pink flowers. One of the most desirable. July and August. 4 to 6 in.

*ternatum. Prostrate and creeping. White flowers in rosettes at the end of barren shoots. 6 to 8 in. long.

yosemitense. Fleshy, bluish green leaves of odd angular shape and arranged in half closed rosettes, Light yellow flowers. 50c. each, $\$ 5.00$ per doz.

SEMPERVIVUM (Houseleek or Hen-and-chickens). Succulent leaves in the form of rosettes, varying in color. Do best in sandy soils and sunshine.

*arachnoideum minor (Small Cobweb Houseleek). Silvery threads from tip to tip of the rosettes form a cobweblike structure. An odd and interesting variety. Flowers bright red. 30c. each, $\$ 3.00$ per doz.

*doellianum. Gray rosettes turning red and closing up in the Fall. Red flowers.

*globiferum. Gray green leaves lightly tipped brown, in flattened rosettes. Pale yellow flowers.

*fimbriatum. Similar to doellianum but with rose flowers and larger rosettes.

*SHORTIA galicifolia (Oconee-bells). Rare evergreen. Native of the mountains of North and South Carolina. White flowers an inch across, fine petals notched on the edges in early Spring. Plant in rich soil in the shade. $35 \mathrm{c}$. each, $\$ 4.00$ per doz.

SIDALCEA. Native. For the border and wild garden and of easy cultivation.

Rose Queen. Rosy pink flowers on erect stems in Midsummer. 2 to $3 \mathrm{ft}$.

Plants 25c. each, $\$ 2.50$ per doz., unless otherwise noted 
SILENE (Catchfly). This class of plants blooms nearly all Summer in the rock garden and needs about the same conditions as the pinks.

*alpestris. Pure white flowers in May and June. A very dainty dwarf plant.

*maritima (Sea Pink). White flowers about 3 in. high.

*maritima florepleno. Same as the above but the blooms are double. 35c. each, $\$ 4.00$ per doz.

*schafta (Autumn Catchfly). Masses of bright pink flowers from July to October. 4 to 6 in.

STACHYS (Woundwort or Betony). Any garden soil in the open.

*lanata (Lambs Ears). Decorative and grown principally for the effect of its soft, white, woolly leaves. Flowers purplish pink. A worthy bedding plant. 12 to 18 in.

STATICE (Sea Pink or Thrift). Thrive in any soil. For border, rock garden, and for edging. The blooms are cut and dried for bouquets.

latifolia (Sea-lavender). Tiny, lavender flowers on sprays for Midsummer. $2 \mathrm{ft}$.

STOKESIA (Stokes Aster or Cornflower Aster). Native. Are hardy but need protection in Winter. Well drained, sandy loam.

alba. A lovely all Summer flower resembling a large Cornflower. White. $3 \mathrm{ft}$. cyanea. A blue form of the above. $3 \mathrm{ft}$.

TEUCRIUM (Germander). For the garden, rock garden or wild garden. Any good soil chamaedrys. A splendid border plant for late Summer bloom with its long, showy flowers, in color red purple or bright rose with red and white spots. 1 to $2 \mathrm{ft}$. 35̃c. each, $\$ 4.00$ per doz.

THALICTRUM (Meadowrue). The fernlike foliage and small flowers in panicles or terminal clusters make this an interesting group for the border or wild garden. They thrive in a loamy soil, well drained.

adiantifolium. Yellow flowers. Foliage resembling that of the Maidenhair Fern. 3 to $4 \mathrm{ft}$. June.

aquilegifolium album. Masses of pure white flower with graceful foliage similar to that of the Columbine. June to July. 2 to $3 \mathrm{ft}$.

flavum. Yellow flowers. About $4 \mathrm{ft}$.

glaucum. Bronze yellow flowers on $4 \mathrm{ft}$. stems in June. Glaucous foliage, finely cut.

THERMOPSIS. Requires deep, well drained soil.

carolinianum. A handsome, tall perennial for the back of the border. Yellow spikes of bloom in June and July. Plant with Delphiniums for a very lovely effect. $5 \mathrm{ft}$.

THYMUS (Thyme). We know of no more useful or charming family of plants than this one. No rock garden is complete without these shrubs or subshrubs, and they make attractive ground covers for banks and Tulip beds. Their mintlike fragrance is not the least of their attractions.

*citriodorus argenteus. Silverleaved. Lemon-scented. 8 to 12 in. $30 \mathrm{c}$. each, $\$ 3.00$ per doz.

*citriodorus aureus. Lemon-scented, with golden leaves. 8 to 12 in. $30 \mathrm{c}$. each, $\$ 3.00$ per doz.

*lanuginosus (Woolly-leaved Thyme). A creeping variety with grayish foliage and rosy lilac flowers. 30c. each, $\$ 3.00$ per doz.

*serpyllum albus (White Mountain Thyme). Dark green foliage in dense mats covered with tiny white flowers. 30c. each, $\$ 3.00$ per doz.

*serpyllum coccineum (Creeping Thyme). Dark green foliage in mats spreading rapidly. Tiny purple flowers in early Spring.

*vulgaris (Common Thyme). Fragrant foliage Tiny, pale lavender flowers in June and July. 12 to 18 in.

TRADESCANTIA (Spiderwort). Native. Easily grown in the open.

*virginiana (Jobs-tears). Old fashioned and unassuming but very appealing with its drooping, dark blue flowers and reedy foliage. About $15 \mathrm{in}$. high and blooms throughout the Summer.

TRITOMA. Hardy, but need heavy covering in the Winter. For safety the corms may be dried after blooming, stored, and replanted the following season as with the Gladiolus.

grandiflora (Red Hot Poker, Flame Flower, or Torchlily). Red blossoms with a long period of bloom. August to October. 3 to $4 \mathrm{ft}$. $35 \mathrm{c}$. each, $\$ 4.00$ per doz.

TROLLIUS. Thrives in moist soil.

*europaeus Hybrids (Globeflower). A desirable plant of upright and sturdy habits with glorious buttercup shaped blessoms of rich orange. About 1 to $2 \mathrm{ft}$. high, blooming from May to August. 35c. each.

Plants 25c. each, $\$ 2.50$ per doz., unless otherwise noted 
TUNICA. Not particular as to soil conditions. Place in edge of border or in the rock garden.

*saxifraga (Tunicflower or Coatflower). Minute, grasslike foliage covered with tiny, pale pink flowers throughout Summer. Especially adapted to the rock garden. About 6 in.

VALERIANA (Valerian). Easily grown in the border.

officinalis (Garden Heliotrope or Common Valerian). Light, feathery heads of minute, pinkish flowerlets on tall, slender stalks. Valuable chiefly for its fragrance and old garden associations. May and June. 3 to $4 \mathrm{ft}$.

VERBENA. A sunny well drained location is necessary.

*canadensis. Lilac to rosy purple blooms somewhat resembling the annual type in habit of growth and appearance. This charming and entirely hardy perennial is sadly neglected. 40c. each, $\$ 4.40$ per doz.

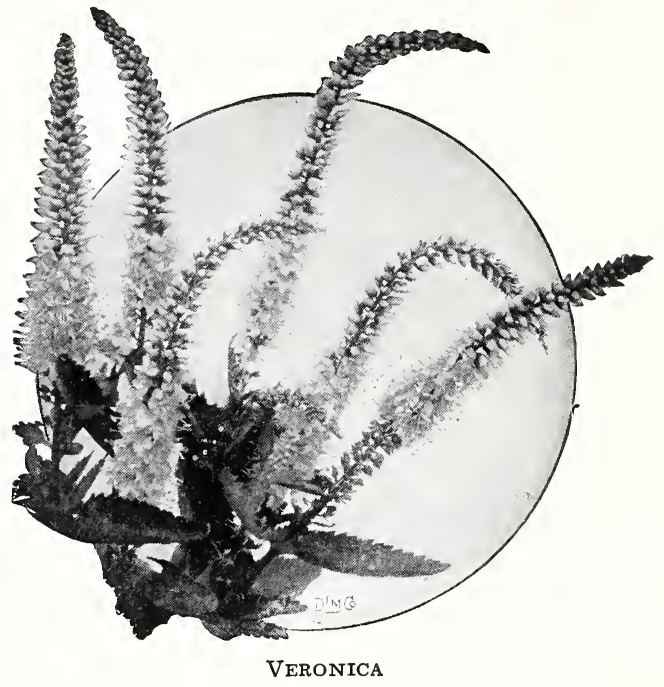

VERONICA (Speedwell). One of the most satisfactory groups for the rock garden or border on account of hardiness and their many attractive forms. They do best in well drained soil in full sunlight.

*amethystina (Speedwell). Forms low bushes of nearly clear blue flowers in May and June. About 12 in.

*erica. A dainty variety with delicate pink flowers somewhat resembling Heather. June and July. 18 in.

*filiformis. A prostrate, spreading variety. Flowers are blue supported on threadlike stems. An exquisite perennial with evergreen foliage. 2 in. 40c. each, $\$ 4.50$ per doz.

*gentianoides (Gentian Speedwell). Pale blue flowers edged dark blue in spikes and of good size. A lovely variety. We have the true dwarf form. June to July. 8 in. $35 \mathrm{c}$. each, $\$ 4.00$ per doz.

*incana. Gray foliage with lavenderlike spikes in Midsummer. 12 in

longifolia. Covered with innumerable slender, lavender spires throughout the garden season. 2 to $3 \mathrm{ft}$.

longifolia, Blue Jay. Stronger growing variety of the above with lighter colored flowers. 2 to $3 \mathrm{ft}$. $35 \mathrm{c}$. each, $\$ 4.00$ per doz.

longifolia subsessilis (Japanese Speedwell). The richest and fullest of the Speedwells. Dark purple in color. Midsummer. About $2 \mathrm{ft}$. 35c. each.

*repens. Tiny, evergreen creeper, bearing wee white flowers during May.

${ }^{*}$ rupestris. A low creeping variety with little, blue flowers in Spring. About 4 in. high.

${ }^{*}$ rupestris nana rosea. Bright rose flowers. Similar in habit to the above. End of April to May. 30c. each, $\$ 3.00$ per doz.

*spicata. Blue flowers on $2 \mathrm{ft}$. spikes from June to August.

spicata rosea. Pink blossoms on stalks of many branches. June to September. $2 \mathrm{ft}$.

*teucrium prostrata nana. A diminutive, prostrate variety of Veronica teucrium. Very tidy blue flowers. About 2 in. 30c. each, $\$ 3.00$ per doz.

*teucrium, Royal Blue. Dwarf variety with dense growth and spreading. Blue flowers in May and June. 8 to 12 in. 30c. each, $\$ 3.00$ per doz.

*teucrium trehani. A very choice variety of trailing habit with golden foliage. The blue flowers make an attractive combination with the foliage. About $10 \mathrm{in.} 30 \mathrm{c}$. each, $\$ 3.00$ per doz.

Plants 25c. each, $\$ 2.50$ per doz., unless otherwise noted 
VINCA (Periwinkle), Thrive in moist shady locations.

*minor (Common Periwinkle or Running Myrtle). A shiny, dark green leaf with a purple flower. A trailing, little evergreen for ground cover in shady spots.

*VIOLA (Tufted Pansy). Indispensable for Spring gardens. Similar to Pansies in appearance but are more desirable as they are hardy and the bedding varieties we offer spread more or less rapidly. Will bloom practically all Summer and into the late Fall if the dead blossoms are removed. About 6 in.

Apricot. This variety with its unusual color well deserves its steadily growing popularity. Rich apricot shade tinged orange toward the center. 35c. each, $\$ 4.00$ per doz.

Bizarre. Most unusual and attractive. The two upper

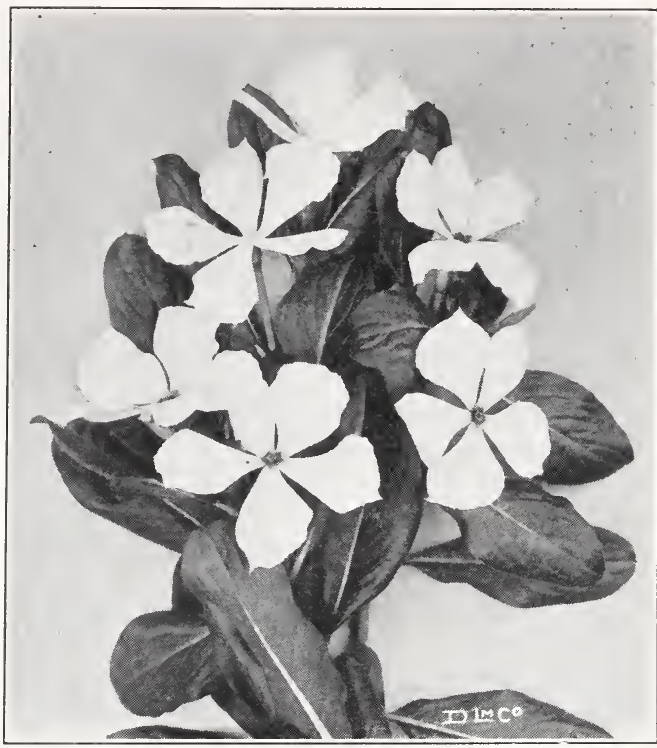

VINCA petals pure violet purple and the lower three clear apricot. 50c. each, $\$ 5.00$ per doz.

Perfection. Bluish mauve shades. Flowers rather small but a very free bloomer.

Giant Yellow. Extra large flowers of a deep golden yellow.

*Jersey Gem. Rich violet, slightly scented. One of the best known of the bedding varieties.

Primrose. Attractive shades of pale primrose color. Large flowers.

Snow White. Very compact in habit and free blooming. Flowers large and snow white with faint penciling.

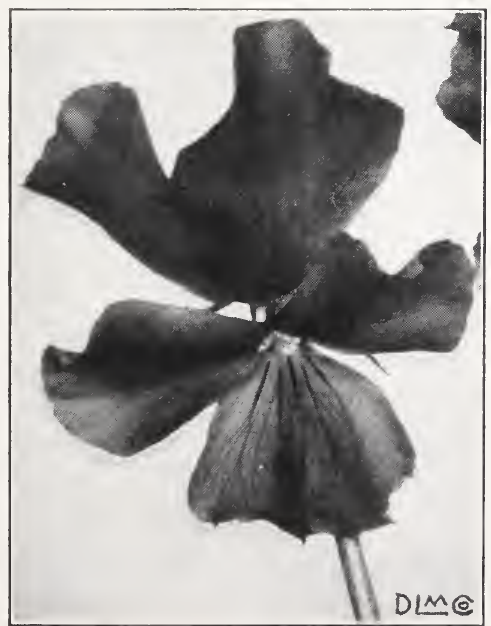

VIOLA

White. Shaped like the native Violet but larger. Sweet scented.

* pedata Bicolor (Birdsfoot Violet). An unusually fine native violet, finely cut leaf, lavender flowers, the two upper petals being much darker. Needs acid soil.

YUCCA. Massed for effects in the garden or with shrubbery, or planted as specimens.

filamentosa (Adams Needle). A decorative and showy plant with white flowers $6 \mathrm{ft}$. 35c. each, $\$ 4.00$ per doz. Plants 25c, each, $\$ 2.50$ per doz.
unless otherwise noted

Springtime Gardens cordially invites all flower lovers to visit us during the garden months. 


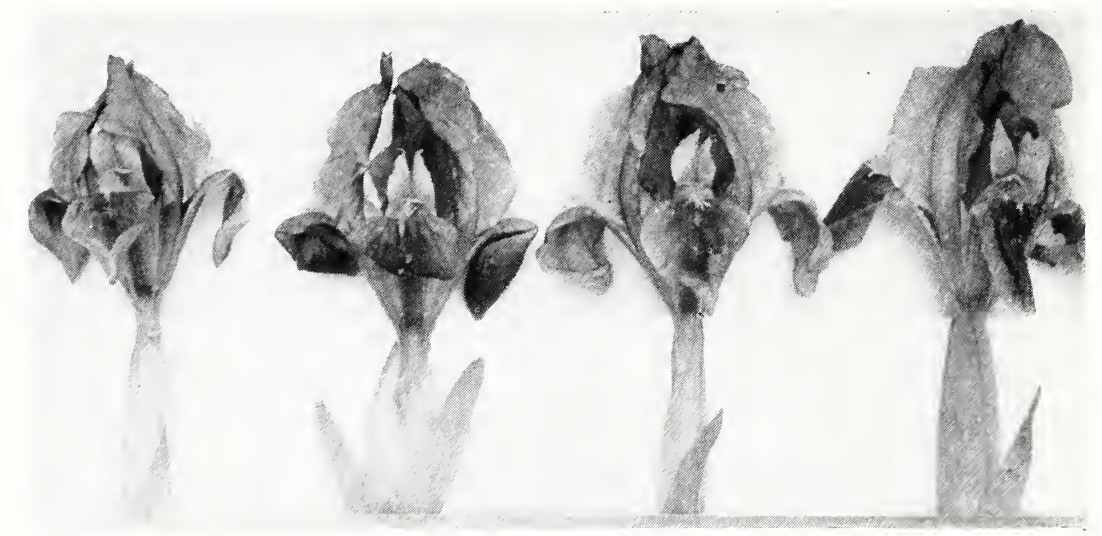

\section{Iris}

Prices are 25c. each for single, strong roots, $\$ 2.50$ per doz., except as noted "S." in the description designates the standards or upright petals; "F." the falls, drooping petals. Varieties especially suitable for the rock garden are designated with an asterisk $\left(^{*}\right)$.

*Cristata (Crested Dwarf Iris). Tiny native species with miniature lavender blooms, striped orange, in Spring. Will grow in full sunlight but thrives best in partial shade. 4 to 6 in.

${ }^{*}$ Cristata alba. Pure white form of the above. Rare. Stock limited. $\$ 2.50$ each.

*Hexagona. A small Iris with large blue blossoms borne close to the ground in June. About 18 in.

${ }^{*}$ Gracilipes. Blue flowers veined lilac. One of the daintiest and most beautiful of all the Iris family. Rare. Stock limited. $\$ 2.00$ each.

*Verna. One of the daintiest of the small Iris family. Exquisitely poised blue flowers with pale yellow centers. Fragrant with evergreen foliage. Needs acid soil.

\section{*Pumila}

These are miniature Irises growing not over 4 inches high and bloom in May and June. Are generally planted around the larger Irises and in groups along the edge of the perennial border.

Sambo. Very dark violet blue.

Excelsa. Pale lemon yellow.

Fairy. Pale blue.

\section{*Pumila Hybrida (Dwarf Bearded Iris)}

These Irises are effective when planted in the border, but are most useful in the rock garden. They bloom very early in the Spring and when planted in groups, or colonies, are very attractive and replace to some extent the smaller Spring bulbs which have become scarce and high in price. The foliage is always attractive.

Aurea Maculata. Yellow. 8 in.

Cyanea. Royal purple with darker shadings. 9 in.

Dittons Purple. Violet purple. Free flowering. 9 in.

Floribunda. Creamy yellow. Large blossoms. 10 in.

Schneekuppe. White. 6 in. 


\section{German Iris}

Thrive best in a good rich garden loam, dug deep, but do well in almost any soil. They need full sunshine. Do not use manure for fertilizer but plenty of bonemeal. Break up the clumps and replant about every three or four years.

Afterglow. Soft, misty lavender with yellow at center. A beautiful Iris but hard to describe. $3 \mathrm{ft}$. $50 \mathrm{c}$. each, $\$ 4.00$ per doz.

Aurea. Pure rich yellow with orange beard. $30 \mathrm{in.}$

Aurora. S. and F. pale lilac pink. Large flowers on strong stems. $4 \mathrm{ft}$. 50c. each, $\$ 4.00$ per doz.

Blue Jay. Good blue shades. About $3 \mathrm{ft}$.; late blooming.

Caprice. S. and F. claret, shading to white at center. Wide open flower.

Celeste. S. and $\mathrm{F}$. soft, pale violet with white beard. A charming variety. $30 \mathrm{in}$.

Dalila. S. ivory white with faint flush of pale rosy lavender; F. bright red with white throat flushed yellow. One of the finest recent creations. $2 \mathrm{ft}$. 50c. each, $\$ 4.00$ per doz.

Dawn. S. and F. pale yellow. A vigorous and free bloomer. 32 in. 50c. each, $\$ 4.00$ per doz.

Dr. Bernice. S. coppery bronze; F. velvety crimson. $2 \mathrm{ft}$. Free flowering. 30c. each, $\$ 3.00$ per doz.

Eldorado. S. yellow brown and heliotrope; F. violet with bronzy gold touches, style arms clear gold. 35c. each, $\$ 3.50$ per doz.

Florentina Alba. Early, free flowering white. Fragrant. 28 in.

Her Majesty. S. rose pink; F. same color with darker veins. 28 in.

Innocenza. S. and F. ivory white slightly reticulated at throat. Late. $2 \mathrm{ft}$.

Iris King. S. old gold; F. rich maroon. $2 \mathrm{ft}$. $35 \mathrm{c}$. each, $\$ 3.50$ per doz.

Isoline. S. soft yellow pink; F. deep old rose. $3 \mathrm{ft}$. Large flowers. 50c. each, $\$ 5.00$ per doz.

Jacquesiana. A distinct, old Iris of brown tones. $4 \mathrm{ft}$.

Kharput. Early variety. S. violet, very broad; F. deep velvety violet. 30 in.

Leonidas. S. clear lavender; F, deeper lavender hugging the stem, making an unusual but attractive form. Large flower. $3 \mathrm{ft}$. 35c. each, $\$ 3.50$ per doz.

Loreley. S. clear pale yellow; F. raisin purple, edged yellow. $2 \mathrm{ft}$. $35 \mathrm{c}$. each, $\$ 3.50$ per doz.

Mme. Chereau. S. and F. white, frilled blue. $3 \mathrm{ft}$.

Ma Mie. S. and F. pure white, pencilled border of blue lines. 50c. each, $\$ 4.00$ per doz.

Mrs. H. Darwin. A free blooming pure white, slightly reticulated with violet at base of falls. $2 \mathrm{ft}$.

Navajo. S. light bronzy yellow, shaded lavender; F. deep maroon, veined white and yellow. 35c. each, $\$ 3.50$ per doz.

Nibelungen. S. fawn; F. bronze purple edged with fawn. 32 in.

Pale Blue. S. and F. pale blue. An old and very attractive variety. Large flowers. $3 \mathrm{ft}$.

Pallida Dalmatica. Sweetly scented, large, spreading flowers. Clear lavender color, shading to pale silvery blue. 3 to $4 \mathrm{f}^{+}$.

Princess Victoria Louise. S. sulphur yellow; F. rich plum, bordered yellow. 30 in.

Prosper Laugier. S. bronzy red; F. ruby velvety. 31 in. 50c. each, $\$ 5.00$ per doz.

Purple King. An early, free flowering variety. Deep violet purple. $2 \mathrm{ft}$.

Quaker Lady. S. smoky lavender, shaded gold; F. amethyst blue shaded yellow. 35 c. each, $\$ 3.50$ per doz.

Queen of May. One of the most beautiful. Soft rose lilac, almost pink. 32 in.

Rembrandt. S. and F. soft blue shades. One of the best blue varieties. $2 \mathrm{ft}$.

Rhein Nixe. S. white; F. raspberry purple with white edge. Branched spikes. $3 \mathrm{ft}$. 35.c. each, $\$ 3.50$ per doz.

Rose Unique. Deep pink. About 20 in. 50c. each, $\$ 4.00$ per doz.

Shrewsbury. S. lilac; F. purple with brilliant orange beard. 30 in. 35c. each, $\$ 4.00$ per doz.

Simplicity. A nearly white flower with pink, styloid petals. 34 in. 75 c. each.

Thelma Perry. S. soft blush; F. rosy mauve. A Pallida variety of vigorous growth. 3 st. 60c. each.

Wyomissing. S. creamy white suffused soft rose; F. deep rose, shading to flesh color on outer edges. 35c. each, $\$ 3.50$ per doz.

Prices are 25c. each for single, strong roots, $\$ 2.50$ per doz., except as noted 


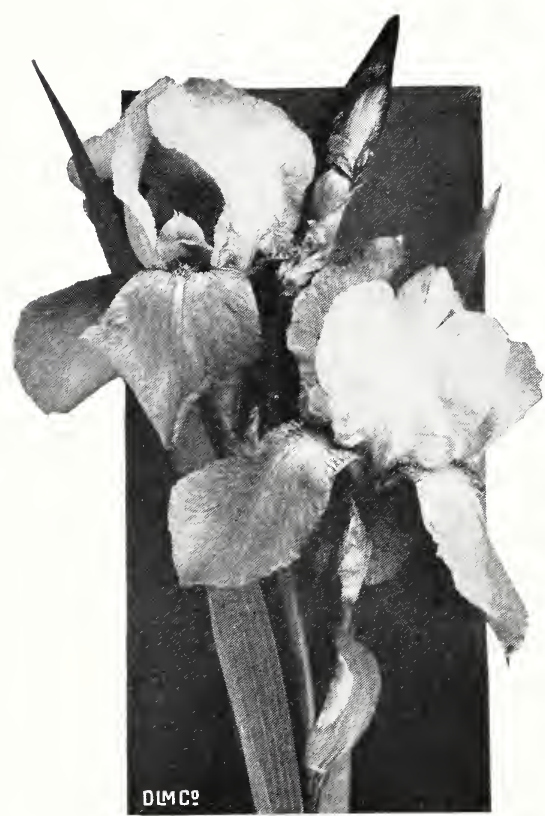

GERMAN IRIS

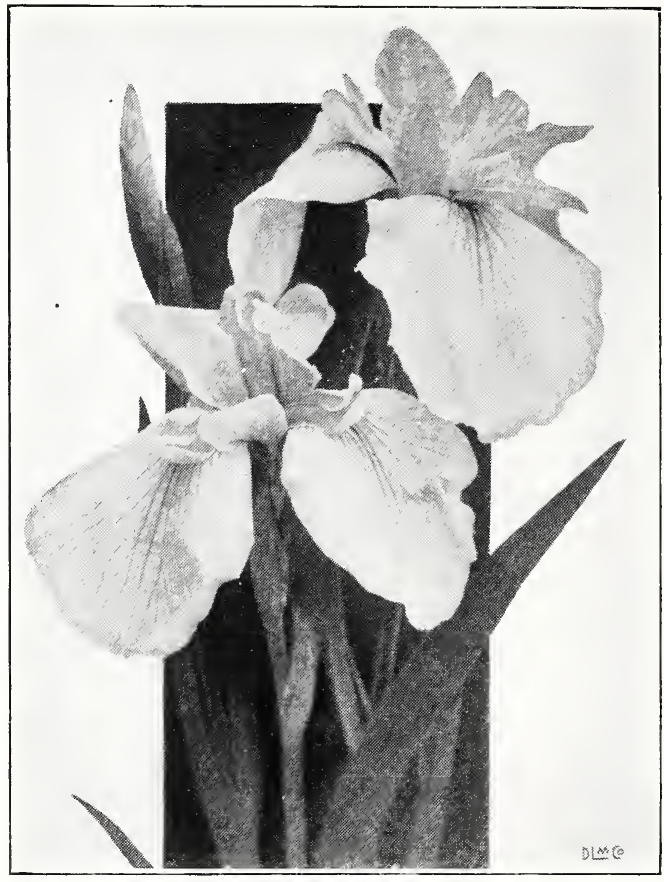

JAPANESE IRIS

\section{Early May-Flowering or Intermediate Iris}

Kochi. Rich claret purple of great intensity. Free blooming and one of the best of its type.

Walhalla. S. light blue lavender; F. velvety purple. Blooms about middle of May. 20 in. 30c. each, $\$ 3.00$ per doz.

\section{Japanese Iris}

These Irises should be heavily mulched in the Winter. Rich, deep soil with plenty of cow manure. Do not use bonemeal. Supply all possible moisture from April to July, but should be fairly dry by Winter.

Blue Flag. Indigo blue, white veined. Yellow at base. 6 petals. $35 \mathrm{c}$. each, $\$ 350$ per doz. Blue Danube. Rich pure blue; 6 petals. $50 \mathrm{c}$. each, $\$ 5.00$ per doz.

Eclipse. Velvety purple; 6 petals. $35 \mathrm{c}$. each, $\$ 3.50$ per doz.

Fascination. Blue lightly veined white with pink tinge. $50 \mathrm{c}$. each, $\$ 5.00$ per doz. Gold Bound. Pure white, yellow center; 6 petals. 35c. each, $\$ 3.50$ per doz.

Kumo-no-obi. Lavender blue; 6 petals. 35c. each, $\$ 3.50$ per doz.

\section{Siberian Iris}

Rich soil with abundance of humus or well rotted cow manure. Do not use bonemeal. Plenty of moisture in the Spring.

Sibirica, Snow Queen. Large, pure white.

Sibirica, Perrys Blue. The best of the Siberian Iris and a rare variety. Horizontal falls; the whole flower clear blue. 3 to $4 \mathrm{ft}$. high. $50 \mathrm{c}$. each, $\$ 5.00$ per doz.

Dark Purple. Tall, about $3 \mathrm{ft}$.

Dark Purple. Medium, about $2 \mathrm{ft}$.

Prices are $25 \mathrm{c}$. each for single, strong roots, $\$ 2.50$ per doz., except as noted 


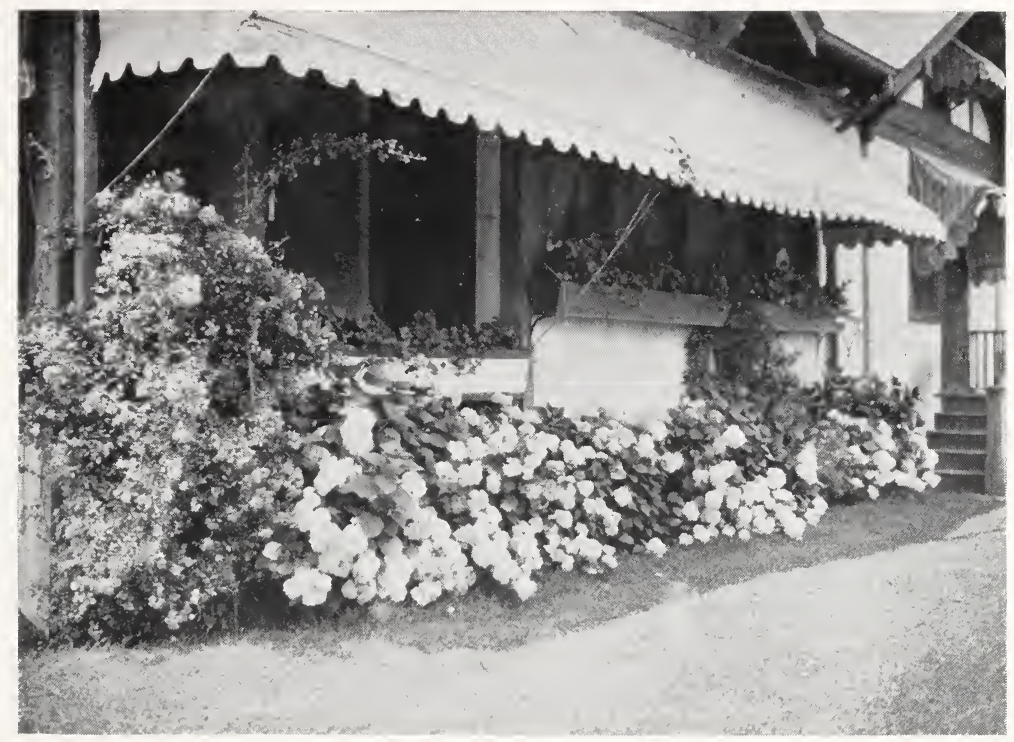

\section{Shrubs}

Note-Heights of shrubs as given in this list are not the ultimate heights to which the shrubs will grow, but indicate the height of shrub which will be furnished at the price designated.

ABELIA chinensis grandiflora. The entire plant is covered from Summer until Fall with Heatherlike, pinkish white flowers. A low growing shrub of graceful habit. 3 yr. old plants, $\$ 1.25$ each.

ACANTHOPANAX pentaphyllum (Fiveleaf Aralia). Good foliage and of graceful arching habit. 4 to $5 \mathrm{ft}$. $\$ 1.25$ each.

AZALEA hinodegiri. Practically covered in the Spring with rosy pink flowers. A nearly evergreen variety. Assorted sizes, ranging from $\$ 1.00$ to $\$ 6.00$ each.

AMYGDALUS (Prunus). Doubleflowering Peach White. $3 \mathrm{ft} . \$ 1.25$ each. roseaplena, Doubleflowering Peach Pink. 3 to $4 \mathrm{ft}$. $\$ 1.50$ each. rubroplena, Doubleflowering Peach Red. 3 to $4 \mathrm{ft}$. $\$ 1.50$ each.

BERBERIS thunbergi (Japanese Barberry). The prettiest of hedge plants, with bright red berries to brighten the dull Winter days. 15 to 18 in. plants, $35 \mathrm{c}$. each, $\$ 25.00$ per $100 ; 24$ to 30 in., 45c. each, $\$ 30.00$ per 100 .

BUDDLEIA (Butterflybush). Sprays of soft lavender through Summer and early Fall make this shrub desirable for gardens. Grows 6 to $8 \mathrm{ft}$. high. Large plants, $\$ 1.00$ to $\$ 1.75$ each.

CALLICARPA purpurea. One of the loveliest of the small shrubs. Suitable for the perennial border. Pink flowers in early Spring, followed by clusters of small, mauve berries in the Fall. 2 to $3 \mathrm{ft}$., $\$ 1.50$ each.

CALYCANTHUS floridus (Common Sweetshrub). Reddish brown, spicy flowers in June. 3 to $4 \mathrm{ft}$. $\$ 1.50$ each.

CLETHRA alnifolia (Sweet Pepperbush). Fragrant flowers in spikes from; July to September. Plant in a moist, shady location. 3 to $4 \mathrm{ft}$. $\$ 1.25$ each.

CORNUS flaviramea (Golden-twigged Dogwood). 3 to $4 \mathrm{ft}$. $\$ 1.00$ each. stolonifera (Red-osier Dogwood). 3 to $4 \mathrm{ft}$. $\$ 1.00$ each. 
COTONEASTER. Hardy in the northern United States. Full sun and well drained soil are essential. Varieties listed below are especially suitable for the rock garden. *horizontalis (Rock Cotoneaster). Grows to $2 \mathrm{ft}$. Semi-evergreen, the branches spreading horizontally. Pink flowers and red berries. \$1.00 each.

*microphylla (Rockspray). Grows to 30 in. Very small, shiny, dark green leaves. Evergreen and branches spread horizontally, white flowers generally singly, and red berries. $\$ 1.00$ each.

*microphylla thymifolia (Thyme Rockspray). Grows to $2 \mathrm{ft}$. A variety of the above with narrower leaves and the flowers in clusters of two to four. $\$ 1.00$ each.

CYDONIA japonica (Japanese Quince). Well known, cheerful, cerise blossoms in early Spring. 2 to $3 \mathrm{ft}$. $\$ 1.00$ each.

*DAPHNE cneorum (Garlandflower). The prettiest of the low growing evergreen shrubs. Indispensable for the rock garden. Pink, fragrant flowers at their best in May but blossoming intermittently throughout the Summer. $\$ 1.50$ to $\$ 3.00$ each.

DEUTZIA gracilis. White flowering Spring shrub. 2 to $3 \mathrm{ft}$. $75 \mathrm{c}$. each.

ELAEAGNUS umbellata. Attractive shrub, principally valuable for its tiny, grapelike clusters of green berries, turning red in the Fall. 4 to $5 \mathrm{ft}$. $\$ 1.50$ each.

EUONYMUS alatus (Winged Euonymus). Of interest because of its corklike bark as well as its red berries. 2 to $3 \mathrm{ft}$. $\$ 1.25$ each.

europaeus. Another red berried shrub, generally taking a treelike form. 3 to $4 \mathrm{ft}$. $\$ 1.00$ each, 4 to $5 \mathrm{ft} . \$ 1.25$ each.

radicans vegetus. A shiny leafed, vigorous and robust Wintercreeper. Half-shrub, half vine. Sometimes bearing orange red berries in late Fall. $\$ 1.00$ to $\$ 3.00$ each.

FORSYTHIA suspensa (Weeping Golden Bell). Tall shrub with gracefully arching branches. Golden yellow bells appearing before the leaves in early Spring. 75c. to $\$ 2.50$ each.

viridissima (Golden Bell). An erect form of the above. $75 \mathrm{c}$. to $\$ 2.50$ each.

KALMIA latifolia (Mountain-laurel). The hardiest of our native evergreen shrubs but requires partial shade. Lovely pink blossoms in June. 18 in. $\$ 2.00$ each and up to $3 \mathrm{ft}$. at $\$ 5.00$ each.

KERRIA japonica (Globeflower). Double golden yellow flowers on graceful stems, blooming throughout the Summer. Spreads rapidly. One of the few shrubs which thrives equally as well in the shade as in full sunshine. 3 to $4 \mathrm{ft} . \$ 1.50$ each.

KOLKWITZIA amabilis (Beautybush). A recent introduction from China. Very highly prized on account of its rare distinction and unusual wealth of bloom. Arching sprays of pale pink blossoms cover the bush in June. Well established plants $\$ 3.00$ each; smaller plants, 50c. and $\$ 1.00$ each.

LONICERA tatarica (Tatarian Honeysuckle). A most cheerful and adaptable shrub. Pink or white. About $3 \mathrm{ft}$. $\$ 1.00$ each.

MAHONIA aquifolium (Oregon Hollygrape). A shrub for a half shady location. Yellow flowers in May with blue black berries in the Fall. The green leaves are shiny and turn scarlet after frost. 1 to $2 \mathrm{ft}$. $\$ 1.00$ to $\$ 2.00$ each.

MALUS atrosanguinea (Carmine $\mathrm{Crab}$ ). Single, deep carmine blossoms literally cover the boughs in early Spring. 5 to $6 \mathrm{ft}$. $\$ 2.50$ to $\$ 3.00$ each.

floribunda (Japanese Flowering Crab). Another Spring flowering Crab with pink buds and white flowers. 5 to $6 \mathrm{ft}$. $\$ 2.50$ to $\$ 3.00$ each.

ioensis plena (Bechtel Crab). By far the loveliest of the blossoming Crabs. Its clear pink flowers resemble miniature, double Roses. Late blooming. 4 to $5 \mathrm{ft}$. $\$ 3.00$ to $\$ 4.00$.

OXYDENDRUM arboreum (Sourwood). Clusters of creamy white flowers in Midsummer. Good, shiny, leathery foliage, somewhat resembling Rhododendrons in shape. Turns scarlet in Autumn. 4 to $5 \mathrm{ft}$. $\$ 3.00$ each.

PHILADELPHUS lemoinei (Mockorange), $3 \mathrm{ft}$. $75 \mathrm{c}$. each.

PRUNUS glandulosa (Amygdalus nana) (Doubleflowering Almond). One of the earliest flowering shrubs and a very beautiful one. The bush is hidden by a mass of pink bloom. $2 \mathrm{ft}$. $\$ 1.00$ each.

pissardi (Purpleleaved Plum). Pink blossoms, but most useful owing to its dark purple foliage. 3 to $4 \mathrm{ft}$. $\$ 1.25$ each.

triloba plena (Doubleflowering Plum). Double pink flowers appear before the leaves. In April and May. 2 to $3 \mathrm{ft}$. $\$ 1.00$ each. 


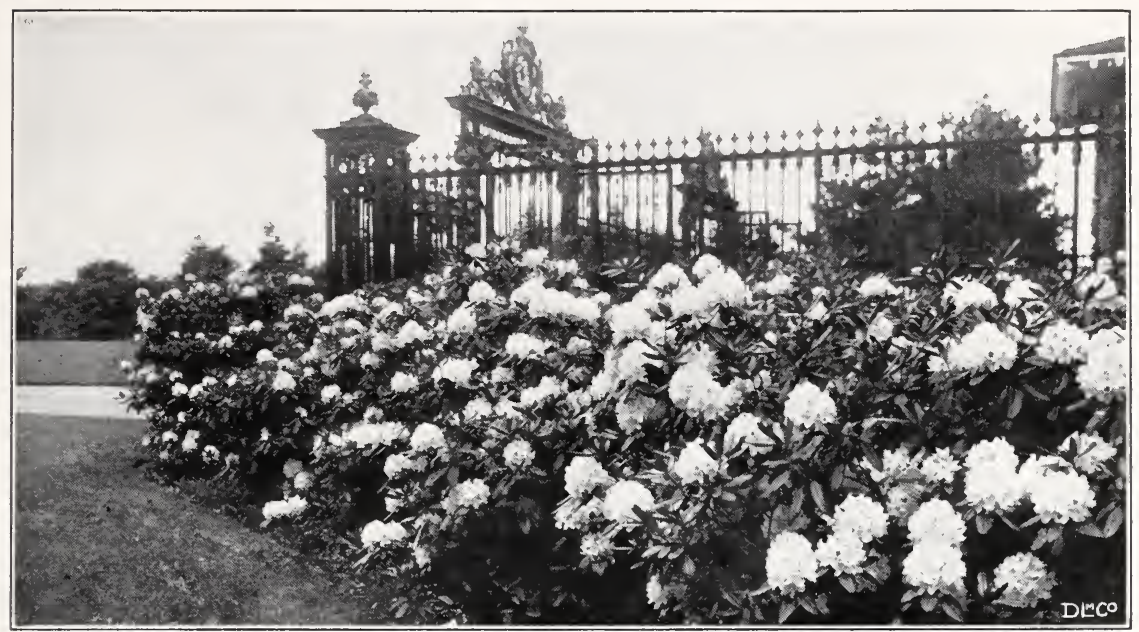

A RHOdODENDRON Planting

RHODODENDRON maximum (Rosebay Rhododendron). Evergreen, handsome foliage with freely produced flowers in May and June. Requires partial shade. $2 \mathrm{ft}$. $\$ 2.50$ each and up to $6 \mathrm{ft}$. at $\$ 10.00$ each.

SPIRAEA Anthony Waterer. A pretty, low shrub for small hedges, or individual plants with bright pink blossoms in the Summer. $2 \mathrm{ft}$. \$1.50 each.

thunbergi (Thunberg Spirea). Feathery light green leaves with good Autumn coloring. Does well in seaside plantings. Pure white flowers cover the arching branches in April and May. 2 to $3 \mathrm{ft}$. $\$ 1.00$ each.

vanhouttei. The most common and yet one of the most beloved of the early shrubs. White garlands cover the bush. 3 to $4 \mathrm{ft}$. $75 \mathrm{c}$. to $\$ 1.25 \mathrm{each}$.

SYMPHORICARPOS racemosus (Snowberry). Dwarf shrub with tiny pink flowers in early Summer followed by clusters of lovely white berries which remain until early Winter. Grows 3 to $4 \mathrm{ft}$. high. $\$ 1.00$ each.

vulgaris (Redfruited Currant). Habit of growth similar to the Snowberry but with small, decorative red berries on under part of stem. Grows 3 to $4 \mathrm{ft}$. \$1.50 each.

SYRINGA vulgaris (Common Purple Lilac). The old fashioned variety. $2 \mathrm{ft} .50 \mathrm{c}$. each to $4 \mathrm{ft}$. at $\$ 1.25$ each.

vulgaris alba. A fragrant white variety of the above. $2 \mathrm{ft}$. $75 \mathrm{c}$. each to $4 \mathrm{ft}$. at $\$ 1.50$ each.

VIBURNUM opulus (European High Bush Cranberry). Gay bunches of bright red berries in the Fall. Unusually handsome leaf. 2 to $3 \mathrm{ft}$. $\$ 1.50$ each.

tomentosum (Doublefile Viburnum). White blossoms in flat heads in June. The red to black berries in the Fall add color to the planting. 3 to $4 \mathrm{ft}$. $\$ 1.25$ each.

WEIGELA hybrida, Eva Rathke. A red flowering variety which blooms several times throughout the Summer. 2 to $3 \mathrm{ft}$. $\$ 1.00$ each.

rosea. The Spring blooming pink variety. 3 to $4 \mathrm{ft}$. $\$ 1.25$ each.

Order your bulbs for Fall planting in the Spring while the beauty of the varieties you have seen is still fresh in your mind. 


\section{Trees}

*JUNIPERUS excelsa stricta (Spiny Greek Juniper). Grows slowly to 4 or $5 \mathrm{ft}$. Compact and of pyramid shape. Handsome gray green foliage. Useful in the rock garden or as single specimens, 18 in. $\$ 1.50$ each.

*PINUS montana mughus (Mugho Pine). Grows to about $3 \mathrm{ft}$., but forms a round topped bush. On account of its graceful, spreading habit and slow growth is a splendid addition to the rock garden. 6 to 8 in. $\$ 1.50$ each, 9 to 12 in. $\$ 3.00$ each.

SORBUS aucuparia (European Mountain-ash). An attractive tree with its fragrant blossoms followed by orange red berries greatly favored by the birds. Thrives best in acid soil. 6 to $8 \mathrm{ft}$. $\$ 1.50$ each.

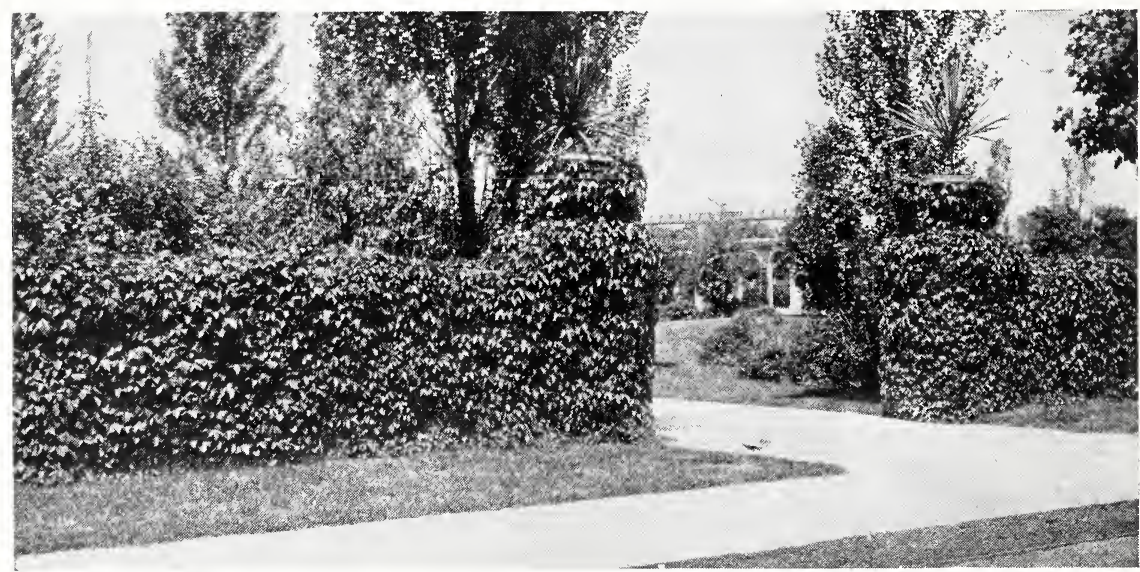

\section{Vines and Climbers}

AMPELOPSIS heterophylla (Porcelain Ampelopsis). A quick growing, sturdy vine for hiding unsightly garden backgrounds. Its principal charm is the beauty of the large clusters of various colored berries on the same stem in the Fall. 4 in. pots. $75 \mathrm{c}$. each.

BIGNONIA grandiflora (Trumpet Vine). A good climber with artistically shaped leaves and graceful habit, but chiefly valuable for its large, reddish henna blossoms in Midsummer. $\$ 1.00$ each.

CLEMATIS paniculata. Sweet smelling, white, starlike flowers in countless numbers cover the pretty vine in August and September. 50c. each.

ENGLISH IVY. Pot grown plants of this valuable evergreen for rockery and walls. 35c. to $75 \mathrm{c}$. each.

*EUONYMUS kewensis. The small, dark green leaves, grow close to the ground making this variety desirable for the rock garden and under trees where grass is hard to grow. 50c. each.

radicans (Evergreen Bittersweet). A most desirable evergreen vine for covering low walls. 2 yr. old vines. $75 \mathrm{c}$. each.

radicans variegata. A green and white variety in habits similar to the above. $1 \mathrm{yr}$. old plants. 50c. each.

JASMINUM nudiflorum. A hardy variety of this charming vine. Yellow. Should be planted in a sheltered position. 4 in. pots. $75 \mathrm{c}$. each.

LONICERA halliana (Halls Honeysuckle). The evergreen variety with deliciously fragrant white and yellow flowers blossoming off and on through Summer and Fall. $35 \mathrm{c}$. each.

WISTERIA. One of the best of the hardy climbers, succeeding in partial shade as well as full sunlight. Drooping clusters of pale lavender flowers in May. $\$ 1.00$ to $\$ 3.00$ each according to age. 


\section{Climbing Roses}

Strong, 3 yr. old plants, $\$ 1.00$ each, $\$ 10.00$ per doz.

American Pillar. Large, single flowers, 3 to 4 in. in diameter, in immense clusters, practically covering the bush when in full bloom. The color is a dainty shade of pink with white center.

American Beauty. A rich, rosy crimson of good form and a very sturdy grower. One of the best climbing Roses and blooms freely.

Emily Gray. The long, pointed buds are light orange yellow changing to pale orange as they expand. Stems are crimson red and of sufficient length for cutting. The foliage is attractive, being dark green and Hollylike in form. This Rose needs protection north of Philadelphia.

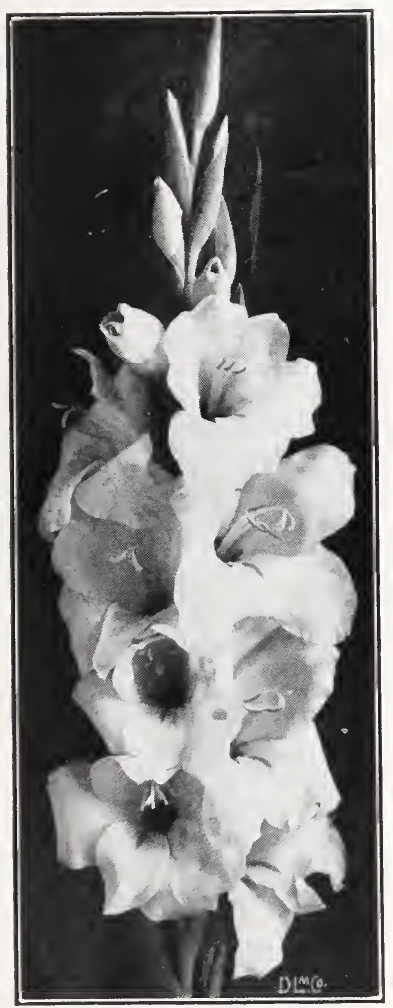

Gladiolus AmERicA

Dr. W. Van Fleet. Here is one of the most popular of the climbing Roses with its perfectly shaped buds and flowers of flesh pink. It is a fine cutting Rose with stems 12 to 18 in. long.

Paul's Scarlet Climber. The flowers are large and of a vivid scarlet. Immense clusters of these brilliant blooms on long stems make it one of the most popular climbers

Silver Moon. The blossoms of this husky growing climber are Clematislike in shape, semi-double, pure white and more than 4 in. across. The shiny foliage has the appearance of being freshly washed. It is unique.

Star of Persia. Large, semi-double, bright yellow flowers which last several weeks and do not fade. This is a new and worthwhile variety.

\section{Gladiolus}

America. Beautiful soft flesh pink. A fine variety for bedding or cutting. 6c. each, 60c. per doz.

Halley. Delicate salmon pink with open flowers 7c. each, 75c. per doz.

Peace. Pure white flowers of great size, the lower petals touched with carmine. $10 \mathrm{c}$. each, $\$ 1.00$ per doz.

Niagara. Delicate yellow cream, marked with rosy carmine in throat. $10 \mathrm{c}$. each, $\$ 1.00$ per doz.

Red Shades. An assortment of attractive red shades. Large flowers. 8c. each, 85c. per doz.

1910 Rose. Early bloomer. Rose pink, lower petals striped white. 8c. each, $85 \mathrm{c}$. per doz.

Schwaben. Very large blooms of light yellow. 10c. each, $\$ 1.00$ per doz.

\section{Fall Bulbs}

A list of charming and desirable Fall bulbs will be mailed about August if requested. The clear colored, sturdy varieties of easy culture have been selected and include Tuilps, Daffodils, Grape-hyacinths, and Scillas. These Spring blossoming treasures are absolutely necessary to the carefully planned garden. 


\section{Common Names}

In the following tables will be found the common names of plants listed in our catalog. The botanical name follows the common name and a brief description of the plant will be found under the latter in the body of the catalog.

\section{Herbaceous Perennials}

Adams Needle. Yucca

Alkanet. Anchusa

Alum Root. Heuchera

Babysbreath. Gypsophila

Balloon Flower. Platycodon

Basket of Gold. Alyssum saxatile

Beebalm. Monarda didyma

Bellflower. Campanula

Bergamot. Monarda didyma

Betony. Stachys

Blackberry Lily. Pardanthus chinensis

Blanketflower. Gaillardia

Blazing-star. Liatris

Bleedingheart. Dicentra spectabilis

Blister Cress. Erysimum

Bloodroot. Sanguinaria

Bluebells. Mertensia

Bluebells of Scotland. Campanula rotundifolia

Blue Bonnet. Scabiosa caucasica

Blue Butterfly. Delphinium chinense

Blue Flax. Linum perenne

Blue Phlox. Phlox divaricata

Bonseset. Eupatorium

Bugloss. Anchusa

Bugle Weed. Ajuga

Bunch Primrose. Primula polyantha

Burning Bush. Dictamus

Buttercup. Ranunculus

Butterfly Weed. Asclepias

Button Snakeroot. Liatris

Campion. Lychnis

Candytuft. Iberis

Canterbury-bells. Campanula medium

Carpathian Harebells. Campanula carpatica

Cat Mint. Nepeta mussini

Catchfly. Silene

Checkerberry. Gaultheria

Chedder Pink. Dianthus caesius

Chickweed. Cerastium

Chimney Bellflower. Campanula pyramidalis

Clustered Bellflower. Campanula glomerata

Coat-Flower. Tunica saxifraga

Columbine. Aquilegia

Coneflower. Rudbeckia

Cornflower Aster. Stokesia

Crosswort. Crucianella

Crowfoot. Ranunculus

Cupid's Dart. Catananche

Cinquefoil. Potentilia

Daylily. Hemerocallis

Devils Paint Brush. Hieracium aurantiacum

Dropwort. Astilbe hexapetala

Dutchmans-breeches. Dicentra cucularia

Edelweiss. Leontopodium

Eryngo. Eryngium

Evening-primrose. Oenothera

Everlasting Pea. Lathyrus

False-chamomile. Boltonia
False-dragonhead. Physostegia

False-indigo. Baptisia

Fescue. Festuca

Field Balm. Nepeta Glechoma

Flame Flower. Tritoma

Flax. Linum

Fleabane. Inula

Forget-me-not. Myosotis

Gasplant. Dictamus

Gentian. Gentiana

Germander. Teucrium

Ghost Plant. Artemisia Silver King

Giant Daisy. Pyrethrum uliginosum

Globeflower. Trollius

Globethistle. Echinops

Golddust. Alyssum saxatile

Golden Drop. Onosma stellulatum

Golden Glow. Rudbeckia lanceolata

Golden Marguerite. Anthemis

Goldentuft. Alyssum saxatile

Greek-valerian. Polemoniun reptans

Groundcherry. Physalis

Groundivy. Nepeta Glechoma

Ground Pink. Phlox subulata

Hardheads. Centaurea

Hardy Cornflower. Centaurea Montana

Hardy Phlox. Phlox decussata

Harebells. Campanula rotundifolia

Hawkweed. Hieracium

Heath. Erica

Heather. Erica vulgaris

Hen-and-Chickens. Sempervivum

Hollyhock. Althaea

Horse Mint. Monarda

Houseleek. Sempervivum

Husk Tomato. Physalis

Iceland Poppy. Papaver nudicaule

Indian Turnip. Arisaema

Jack-in-the-pulpit. Arisaema

Jacobs Ladder. Polemonium

Kenilworth-ivy. Linaria cymbalaria

Kings Spear. Asphodeline Lutea

Knapweed. Centaurea

Lambs Ears. Stachys lanata

Larkspur. Delphinium

Lavender. Lavandula

Lavender-cotton. Santolina incana

Leadwort. Plumbago

Lebanon Candytuft. Aethionema persicum

Leopardbane. Doronicum

Lily. Lilium

Lily-of-the-valley. Convallaria

Liverleaf. Hepatica

Loosestrife. Lythrum

Lovely Phlox. Phlox amoena

Lupine. Lupinus

Madonna Lily. Lilium candidium

Madwort. Alyssum

Maiden Pink. Dianthus deltoides 


\section{HERBACEOUS PERENNIALS - Continued}

Meadowrue. Thalictrum

Michaelmas Daisy. Aster

Milfoil. Achillea

Mint. Mentha

Mistflower. Eupatorium coelestinum

Monkshood. Aconitum

Morning Bride. Scabiosa

Moss Pink. Phlox subulata

Mossy Saxifrage. Saxifraga decipiens

Mountain-bluet. Centaurea montana

Mouse-ear. Cerastium

Mugwort. Artemisia lactiflora

Myrtle. Vinca

Oconee-bells. Shortia

Old Man. Artemisia abrotanum

Old Mans Beard. Saxifraga sermentosa

Old Woman. Artemisia stellariana

Orangecup Lily. Lilium philadelphicum

Oxeye. Buphthalmum

Painted Daisy. Pyrethrum

Peach Bells. Campanula persicifolia

Perennial Pea. Lathyrus

Periwinkle. Vinca

Pincushion Flower. Scabiosa

Pink. Dianthus

Plantainlily. Funkia

Plumepoppy. Bocconia

Plumy Bleedingheart. Dicentra formosa

Poppy. Papaver

Primrose. Primula

Red Hot Poker. Tritoma

Rock Aster. Aster alpinus

Rockcress. Arabis alpina

Rocket. Hesperis

Rockfoil. Saxifraga cordifolia

Rock-Jasmine. Androsace

Rockrose. Helianthemum

Sage. Salvia

Sand-loving Pink. Dianthus arenarius

Sandwort. Arenaria

Savoy. Calamintha

Seaholly. Erỹngium

Sea Pink. Armeria-Silene-Statice
Shasta Daisy. Chrysanthemum maximum

Sneezewort. Helenium

Snow-in-summer. Cerastium tomentosum

Soapwort. Saponaria

Speedwell. Veronica

Spice Pink. Dianthus plumarius

Spiderwort. Tradescantia

Spirea. Astilbe

Spurge. Pachysandra and Euphorbia

Stokes Aster. Stokesia

St. Johnswort. Hypericum

Stone Cress. Aethionema

Stonecrop. Sedum

Strawberry Geranium. Saxifraga sarmentosa

Sunrose. Helianthemum

Sweet-william. Dianthus barbatus

Teaberry. Gaultheria

Thoroughwort. Eupatorium

Thrift. Armeria

Thyme. Thymus

Tickseed. Coreopsis

Tick Trefoil. Desmodium

Tiger Lily. Lilium tigrinum

Toadflax. Linaria

Torchlily. Tritoma

True Asphodel. Asphodeline lutea

Tufted Pansy. Viola

Tunisflower. Tunica

Turtlehead. Chelone

Valerian. Valeriana and Centranthus

Virginia Cowslip. Mertensia virginica

Wallflower. Cheiranthus

Wild Blue Phlox. Phlox linnaeus

Windflower. Anemone

Wintergreen. Gaultheria

Wolfs Head. Euphorbia polychroma

Woodruff. Asperula

Wormwood. Artemisia

Woundwort. Stachys

Yarrow. Achillea

Yellow Tuft. Alyssum argenteum

\section{Shrubs}

Almond-Double Flowering. Prunus glandulosa

Aralia. Acanthopanax pentaphyllum

Barberry. Barberis

Beauty Bush. Kolkwitzia

Butterflybush. Buddleia

Crab-Bechtel. Malus ioensis piena

Crab-Carmine. Malus atrosanguiena

Crab-Japanese Flowering. Malus floribunda

Cranberry. European High Bush. Viburnum opulus

Currant. Red Fruited. Symphoricarpos vulgaris

Dogwood. Golden Twigged. Cornus flaviramea

Dogwood. Red-osier. Cornus stolonifera

Doublefile Viburnum. Viburnum tomen tosum

Garland Flower. Daphne cneorum
Globeflower. Kerria japonica

Golden Bell. Forsythia virdissima

Golden Bell Weeping. Forsythia suspensa

Honeysuckle Tatarian. Lonicera tatarica

Laurel. Kalmia

Lilac. Syringa

Mockorange. Philadelphus lemoinei

Orgon Holly Berry. Mahonia

Peach. Amygdalus

Plum. Doub!e Flowering. Prunus triloba plena

Plum. Purpleleaf. Prunus pissardi

Quince. Japanese. Cydonia japonica

Snowberry. Symphoricarpos racemosus

Sourwood. Oxydendrium arboreum

Sweet Pepper Bush. Clethra alnifolia

Winged Euonymus. Euonymus alatus 


\section{Plants Suitable for the Rock Garden}

Achillea tomentosum

Aethionema persicum

Ajuga genevensis

Ajuga reptans

Alyssum argenteum

Alyssum saxatile

Alyssum wulfianum

Androsace primuloides

Anemone pulsatilla

Arabis alpina

Arabis alpina florepleno

Arabis alpina rosea

Arenaria montana

Arenaria verna

Armeria formosa

Armeria laucheana

Armeria maritima alba

Aster Japanese Hardy

Aster alpinus

Aster subcaeruleus

Astilbe filipendula hexapetala

Aubretia

Calamintha alpina

Campanula carpatica

Campanula carpatica alba

Campanula glomerata

Campanula native

Campanula portenschlagiana

Companula pusilla

Campanula rotundifolia

Cerastium tomentosum

Convallaria

Cotyledon

Crucianella
Delphinium chinense

Dianthus all varieties

Dicentra cucularia

Dicentra formosa

Doronicum

Erica

Erinus

Eryngium

Erysimum

Euphorbia

Festuca

Funkia

Gaultheria

Gentiana

Geum

Gypsophila cerastoides

Gypsophila repens

Gypsophila repens rosea

Helianthemum

Hepatica

Hesperis

Heuchera

Hieracium

Hypericum

Iberis

Inula

Iris, dwarf varieties

Lavandula

Leontopodium

Linaria

Linum

Lychnis alpina

Mazus rugosus

Mentha
Mertensia

Myosotis

Nepeta

Oenothera

Onosma

Papaver alpinum

Papaver nudicaule

Papaver orientale, Mrs. Perry

Phlox divaricata

Phlox subulata

Phlox amoena

Platycodon

Plumbago

Polemonium

Potentilla

Primula

Primula polyantha

Ranunculus

Sanguinaria

Santolina

Saponaria

Scabiosa caucasica

Sedum

Sempervivum

Silene

Stachys

Statice

Thymus

Trollius

Tunica

Verbena

Veronica-low forms

Vinca

Viola

\section{Plants Suitable for the Wild Garden}

Anemone canadensis

Anemone syndesmon thalictroides

Aresaema triphyllum

Asclepias

Asphodeline

Baptisia

Campanula native

Campanula glomerate

Campanula rotundifolia

Dicentra cucularia
Eupatorium

Gaultheria

Gaura

Helenium

Hepatica

Hesperis

Heuchera

Hieracium

Iris, native

Lilium, native
Lythrum

Mertensia

Monarda

Phlox divaricata

Sanguinaria

Sidalcea

Shortia

Stokesia

Teucrium

Thalictrum

Tradescantia

\section{Plants Which Will Grow in Shade or Partial Shade}

Aconitum

\section{Perennials}

Aquilegia

Anemone japonica

Anemone syndesmon thalictroides

Aresaema triphyllum

Asperula hexaphylla

Asperula odorata

Asphodeline lutea

Astible, all varieties

Campanula, all varieties

Chelone

Convallaria majalis

Crucianella stylosa

Dicentra cucularia
Dicentra formosa

Dicentra spectabilis

Funkia

Gaultheria

Gentiana

Hepatica

Heuchera

Lilium

Linaria

Lythrum

Mertensia

Myosotis

Nepeta glechoma

Pachysandra

Plumbago !
Primula

Primula polyantha

Sanguinaria

Saxifraga

Shortia

Vinca

\section{Shrubs}

Clethra alnifolia

Daphne cneorum

Kalmia

Kerria japonica

Mahonia

Rhododendron 


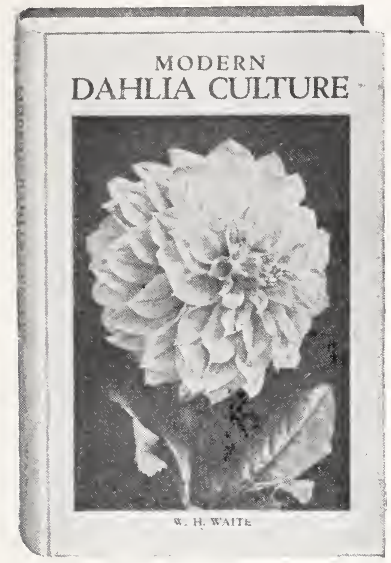

\section{PRACTICAL GARDEN BOOKS}

Written by well-known authorities in a concise and lucid manner, handsomely printed on good paper, profusely illustrated and attractively bound in durable covers.

THE BOOK OF ANNUALS. By Alfred C. Hottes. Over 100 separate species described with full directions for their culture and uses. 182 pages, 155 illustrations. Cloth. Postpaid, $\$ 1.65$.

BULBS THAT BLOOM IN THE SPRING. $B y T . A$. Weston. Covers the fall-planted bulbs that give the earliest flowers and require minimum attention. 144 pages, 60 full-page plates ( 8 in color). Cloth. Postpaid, $\$ 2.15$.

A LiTTLE BOOK OF CLIMBING PLANTS. By A. C. Hottes. Full information on climbers, ground-covers and creepers. 250 pages, 105 illustrations. Postpaid, $\$ 1.90$.

MODERN DAHLIA CULTURE. By Wm. H. Waite, the originator of "Jersey's Beauty" and other highly popular Dahlias. 132 pages with 28 illustrations and 4 color plates. Cloth. Postpaid, \$1.65.

PRINCIPLES OF FLOWER ARRANGEMENT. By Prof. E. A. White. For all those who wish to display flowers to their fullest beauty. 226 pages, 71 illustrations $(6$ in color). Imitation leather. Postpaid, $\$ 3.15$.

GARDEN GUIDE. Each subject written by different experts. Information on every phase of gardening pertaining to the small or average-sized home. 388 pages, 275 illustrations. Cloth. Postpaid, $\$ 1.65$.

HORTUS. By L. H. and E.Z. Bailey. A real dictionary of plants, with an immense amount of reliable information about every ornamental, fruit, and vegetable cultivated in North America, arranged alphabetically with common names cross-referenced. Gives comprehensive information on culture, growing habit, hardiness, uses, soil requirements, transplanting, propagation, native habitat, and the range of cultivation of each plant with illustrated articles on different types of horticulture and cultural methods. 652 pages, 35 illustrations, fabrikoid. $\$ 10.00$.

THE IRIS. By John C. Wister. Presents in a clean, convincing manner the simple requirements of this flower. Intensely interesting. Price $\$ 1.25$.

MILADY'S HOUSE PLANTS. By F. E. Palmer. Tells how to care for and raise all house plants that succeed in the home. 176 pages, 96 illustrations. Cloth. Postpaid, $\$ 1.35$.

PRACTICAL LANDSCAPE GARDENING. By Robt. A. Cridland. Tells how to beautify and landscape your own home grounds. 280 pages with 260 illustrations, plans and sketches. Cloth. Postpaid, $\$ 2.65$.

LANDSCAPING THE SMALL HOME. By E. W. Olver. Written especially for the owner of a small place. Numerous plans and sketches. 160 pages, 52 illustrations. Cloth. Postpaid, $\$ 2.15$.

1001 GARDEN QUESTIONS ANSWERED. By A. C. Hottes. Covers all phases of gardening on the medium sized place-flowers, fruits, vegetables, trees, shrubs, walks, etc. 320 pages, 80 illustrations. Cloth. Postpaid, $\$ 2.15$

THE BOOK OF PERENNIALS. By A. C. Hottes. How to successfully grow and enjoy over 125 species of our most popular and durable border plants. 200 pages, 93 illustrations. Cloth. Postpaid, \$1.65.

AMERICAN ROCK GARDENS. By Stephen F. Hamblin. The author gives in plain, practical style, instructions on how to make a rock garden. A special feature is the many lists of plants for special local conditions. Price $\$ 1.25$.

ROCK GARDEN AND ALPINE PLANTS. By Henry Correvon. Edited by Leonard Barron. 560 pages, 33 illustrations, $6 \times 9$ inches, cloth binding. A splendid book on the subject and valuable as a reference book. Price $\$ 6.00$. 
ROCK GARDEN PRIMER. By A. Thornton. Unusually complete for information on construction. Also gives care and culture of plants. 152 pages, 74 illustrations (4 in color). Imitation leather. Postpaid, $\$ 2.15$.

BOOK OF SHRUBS. By A. C. Hottes. A complete non-technical description of the common species with their characteristics, uses, soil, pruning and propagation. 371 pages, 180 illustrations. Cloth. Postpaid, \$3.15.

STANDARDIZED PLANT NAMES. Designed to serve anyone and everyone who has to do with plants - whether amateur or professional-whether as gardener, student, plant lover, commercial florist, nurseryman or seedsmen, grower, editor, writer, teacher, librarian, etc.-by supplying: A Single accurate name for every plant. Cloth, 548 pages, 45,000 plant names, $5 \frac{1}{2} \times 8$ in. in size. Standard edition, cloth, $\$ 6.00$. Pocket edition, India paper, flexible cover, $\$ 7.50$. Interleaved edition, cloth $\$ 7.50$.

WATER GARDENS AND GOLDFISH. By Sawyer and Perkins. Two closely related subjects treated under one cover. Small to medium pools. 112 pages, 59 illustrations. Cloth. Postpaid, \$1.65.

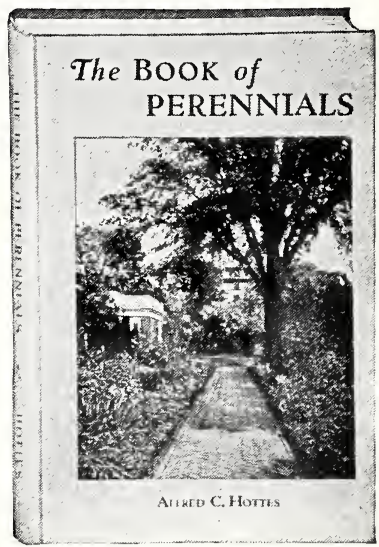

WOMAN'S FLOWER GARDEN. By J. L. Kift. The care and treatment of plants in the home and their cultivation outdoors. 160 pages. 15 illustrations. Cloth. Postpaid, $\$ 1.35$.

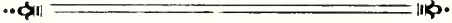 \\ FERTILIZERS}

We use and recommend for general garden use, the lawn, shrubbery, etc., the fertilizers listed below, and can deliver promptly from stock. Local delivery free of charge. Price on quantity a matter of correspondence.

VIGORO-A well balanced fertilizer of unusual strength. The price appears high, but so little is required to secure the desired results that we feel it is one of the best and one of the cheapest on the market. Price $\$ 5.00$ per $100 \mathrm{lbs}$.

Analysis :

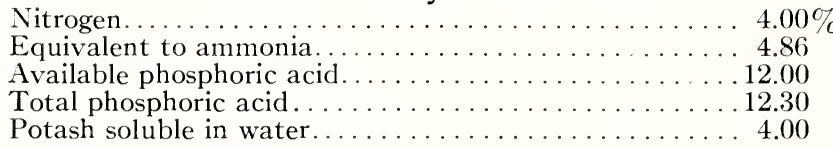

4-8-7 - A fertilizer used to advantage in ordinary garden soils.

Analysis :

Nitrogen.......................... 3.29\%

Equivalent to ammonia.................. . . . . . . . . . . .

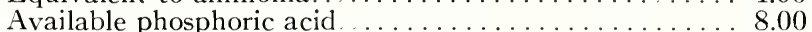

Insoluble phosphoric acid. . . . . . . . . . . . . . None

Total phosphoric acid . . . . . . . . . . . . . 8.00

Potash soluble in water ......................... 7.00

Price, $\$ 2.75$ per 100 lbs.

BONEMEAL-The only safe plant food. Most plants benefit by an application of Bonemeal and there is little danger from burning. We use it the year round. Keep a bag of Bonemeal handy in some dry place so that when you weed or transplant you can work a little in and maintain soil fertility. High grade steamed Bonemeal, $\$ 3.00$ per 100 lbs.

SHEEP MANURE-This is a quick acting fertilizer and easily handled. We furnish a very high grade brand at $\$ 3.00$ per $100 \mathrm{lbs}$.

HYDRATED LIME-Quick working, finely pulverized lime all ready to apply. Price, 70c. per $50 \mathrm{lbs}$ 
God Almighty first planted a Garden-and, indeed, it is the purest of human pleasures; it is the greatest refreshment to the spirits of man without which buildings and palaces are but gross handiworks.

\section{Landscape Gardening}

-Francis Bacon.

A deep rooted love for Gardens, and an understanding of the little Green People who live in them, has been responsible for the establishment of Springtime Gardens. All along the ages simple, kindly souls at times have sensed through their spirits the depth of the beauty of a growing Garden. And now, during this age of hectic scrambling and rather overdone activity, the peace and calm contentment which is the Garden's gift to man, is more than ever to be desired.

\section{ก. \\ Springtime Gardens}

specialize in planning and planting of the Home Grounds, in graceful and charming foundation plantings, in the construction of Gardens from the stately and formal to the "Little Gardens," much beloved by the average busy person who seeks peace and relaxation. Particularly we recommend the friendly and informal Rock Gardens, with their unlimited opportunities for joyous surprises and beauty of design.

Those desiring information on the above subject, or advice as to their own Gardens, may make an appointment with one of our competent representatives.

Springtime Gardens are open to the public every day including Sundays and holidays from 9 a. m. to 5 p. m.

$V$ isitors are always welcome. 
